\title{
MILITARY JURISDICTION OVER CIVILIANS
}

\author{
ROBINSON O. EVERETT*
}

I

\section{INTRODUCTION}

TN A WORLD where the existence of large armed forces and the 1 threat of war appear almost as inescapable as death and taxes, determination of the proper sphere for military authority has proved a delicate and often controversial process. The requirements for accomplishing military objectives and for assuring an adequate national defense must be balanced carefully against the danger of becoming a garrison state and sacrificing important civil liberties. Some of the difficulties of achieving a suitable reconciliation are illustrated by several recent unsuccessful attempts to include certain categories of civilians within American military jurisdiction.

\section{A. Martial Law}

In analyzing the amplitude of military jurisdiction over civilians, a distinction should be drawn at the outset between martial law, the law of war, and "military justice."1 Military jurisdiction grounded on martial law has long been sustained, so long as it was limited by the necessity that provided the justification for martial law. Thus, a civilian can be tried by a court-martial or military commission when, by reason of invasion, insurrection, or the like, martial law has been invoked and the civil courts cannot carry on their functions. On the other hand, the Supreme Court ruled in the leading case of Ex parte Milligan, ${ }^{2}$ which pertained to trial by military commission during the Civil War, that civilians could not be subjected to a military trial if conditions did not preclude the civil courts from opening their doors. This doctrine was

* A.B. 1947, LL.B. 1950, Harvard University. Visiting Associate Professor of Law, Duke University; Member of the North Carolina bar. Author, Military JUstice in the ARmed Forces of the UNITEd States (1956). Contributor to legal periodicals.

${ }^{1}$ For a general discussion, see EveretT, Military JUSTiCe IN the ARMEd Forces of THE UNITED STATES ch. 3 (1956). See also Underhill, Jurisdiction of Military Tribunals in the United States over Civilians, 12 CaLIF. L. REv. 75 (1924).

${ }^{2}$ 7x U.S. (4 Wall.) 2 (1866). 
strongly reaffirmed in Duncan $v$. Kahanamoku, ${ }^{3}$ which related to military jurisdiction over civilians in Hawaii after the Pearl Harbor attack.

\section{B. The Law of War}

Trials of civilians by military tribunals have also been rested on the law of war. For instance, the Supreme Court held in Ex parte Quirin ${ }^{4}$ that the law of war-a branch of international law-authorized the trial by military commission of eight spies who disembarked in New Jersey from a German submarine during the early stages of World War II. Even the possible American citizenship of one spy and the availability of American civil courts were not deemed to grant immunity from military trial, ${ }^{5}$ since Congress had authorized such trial pursuant to its constitutional power "to define and punish Piracies and Felonies committed on the high Seas, and offenses against the Law of Nations."'6 With respect to the constitutional safeguards of grand jury and petty jury, the Court reasoned that, ${ }^{8}$

The object was to preserve unimpaired trial by jury in all these cases in which it had been recognized by the common law and in all cases of a like nature as they might arise in the future ... but not to bring within the sweep of the guaranty those cases in which it was then well understood that a jury trial could not be demanded as of right.

Since offenses against the law of war, such as spying, had not been triable by jury at common law, there was now no constitutional right to trial by jury or to trial only in the civil courts. ${ }^{9}$

The law of war is considered to confer upon a victorious belligerent

${ }^{3} 327$ U.S. 304 (1946). The two trials under consideration there had taken place in August 1942 and in 1944, rather than immediately after Pearl Harbor. The Court's opinion interpreted the Hawaiian Organic Act concerning martial law. See also Sterling v. Constantin, 287 U.S. 378 (1932).

317 U.S. I (1942).

- It deserves emphasis that the military trial was before an ad hoc tribunal with its own special rules of procedure, and not a court-martial with procedure provided by the Articles of War and the Manual for Courts-Martial. With a military commission of this sort, the deprivation of safeguards for an accused is especially great. For another case involving a specially-created military commission, see In re Yamashita, 327 U.S. I (1946).

U.S. CoNst. art. I, $\$ 8$, cl. 10.

' $I d$. art. III, $\S_{2}$ and the fifth and sixth amendments. These are discussed in $E x$ parte Quirin, 317 U.S. I, $38-40$ (1942).

${ }^{8}$ Id, at 39 .

'Id. at 40. The Supreme Court drew an analogy to the unavailability of trial by jury for petty offenses, District of Columbia v. Clawans, 300 U.S. 617 (1937); for criminal contempts, Ex parte Terry, 128 U.S. 289 (1888); and in an action for debt to enforce a penalty inflicted by Congress, United States v. Zucker, I6I U.S. 475 (I896). 
the power to govern occupied territory by military courts. In Madsen v. Kinsella, ${ }^{10}$ the Supreme Court held that a military government court sitting in occupied Germany could even try an American wife who had there slain her husband, an Air Force lieutenant. Speaking of military commissions, the court commented: "Since our nation's earliest days, such commissions have been constitutionally recognized agencies for meeting many urgent governmental responsibilities related to war."11 Moreover, absent legislation by Congress to the contrary, the President, as Commander-in-Chief of the Army and Navy, can prescribe the jurisdiction and procedure of such commissions.

\section{C. "Military Justice"}

Purported authorization for the exercise of military jurisdiction over some civilians can also be found in the Uniform Code of Military Justice, ${ }^{12}$ which, as the Articles of War and the Articles for the Government of the Navy previously did, ${ }^{13}$ provides for "military justice" and sets forth certain "rules for the government and regulation of the land and naval forces."14 Among the provisions of the Uniform Code that present problems of military jurisdiction over civilians are: $:^{15}$

${ }^{10} 343$ U.S. 34 I (I952). Cf. Neely v. Henkel, I80 U.S. 109 (Igor) (Cuba after the Spanish-American War); United States ex rel. Mobley v. Handy, I 76 F.2d 49 I (5th Cir.), cert. denied, $33^{8}$ U.S. 904 (I 949) (occupied Germany); United States v. Schultz, I U.S.C.M.A. 5 I2, 4 C.M.R. 104 (1952) (Japan).

${ }^{11}$ Madsen v. Kinsella, 343 U.S. 34I, 346 (1952).

12 The Uniform Code of Military Justice was originally enacted on May 5, 1950, and was contained in 64 Stat. 108, 50 U.S.C. $\$ \S 551-736$ (1952). In 1956, it was recodified, 70A Stat. 36-78, Io U.S.C. $\$ \$ 80$ r-940 (I958).

${ }^{13}$ For some of the historical background of the Uniform Code, see EVERETT, op. cit. supra note I, ch. 2.

1s See U.S. CoNst. art. I, $\$ 8$, cl. I4. Undoubtedly the Uniform Code was primarily intended by its draftsmen to provide "rules for the government and regulation of the land and naval forces." However, in drafting art. 18 of the Code, 70A Stat. 43 (I956), to U.S.C. $\$ 8$ I8 (1958), specific reference is made to the "law of war" as a basis for military jurisdiction; and art. xo4 and so6 of the Code, 70A Stat. 70, 71 (1956), Io U.S.C. $\$ \S 904,906$ ( 1958 ), were probably drawn with the "law of war" in mind. See Ex parte Quirin, 3 I 7 U.S. I (1942).

${ }_{15}$ Problems of military jurisdiction over persons who were, in some sense, civilians might also arise under art. 2 ( 1 ) of the Code, 7oA Stat. 37 (1956), ro U.S.C. $\$ 802$ ( 1 ) ( 1958 ), which treats as subject to the Code, certain "persons lawfully called or ordered into, or to duty in or for training in, the armed forces, from the dates when they are required by the terms of the call or order to obey it," (analogous to the equitable maxim about treating as done that which ought to be done); under art. 2 (3) of the Code, 70A Stat. 37 (1956), ro U.S.C. $\$ 802(3)$ (1958), which covers "members of a reserve component while they are on inactive duty training authorized by written orders which are voluntarily accepted by them and which specify that they are subject to" the Uniform Code (an interesting effort to create jurisdiction by consent); under 
(a) Article 2(ro), which defines as subject to the Code "in time of war all persons serving with or accompanying an armed force in the field. $" 16$

(b) Article 2(II), which defines as subject to the Code $^{17}$

subject to the provisions of any treaty or agreement to which the United States is or may be a party or to any accepted rule of international law, all persons serving with, employed by, or accompanying the armed forces without the continental limits of the United States and outside the following: that part of Alaska east of longitude 172 degrees west, the Canal Zone, the main group of the Hawaiian Islands, Puerto Rico, and tbe Virgin Islands.

(c) Article 2(12), which defines as subject to the Code ${ }^{18}$

subject to the provisions of any treaty or agreement to which the United States is or may be a party or to any accepted rule of international law, all persons within an area leased by or otherwise reserved or acquired for the use of the United States which is under the control of a Secretarv of a Department and which is without the continental limits of the United States ....

(d) Article 3(a), which provides that ${ }^{19}$

subject to the provisions of Article 43, any person charged with having committed, while in a status in which he was subject to this code, an offense against this code, punishable by confinement of five years or more and for which the person cannot be tried in the courts of the United States or any State or Territory thereof or of the District of Columbia, shall not be relieved from amenability to trial by courts-martial by reason of the termination of said status.

art. $2(4)(5)(6)$ of the Code, 70 A Stat. 37 (1956), ro U.S.C. $\$ \S 802(4)(5)(6)$ (1958), which pertain to certain categories of retired and reserve personnel; and art. 2 (7) of the Code, 70A Stat. 37 (1956), 1o U.S.C. $\$ 802(7)$ (1958), which covers military prisoners. See generally EVERETT, op. cit. suppra note I; AYcock \& WURFEL, Military LaW under the Uniform CODE of Military Justice ch. 3 (1955). See also In re Taylor, 160 F. Supp. 932 (W.D. Mo. 1958); United States v. Bledsoe, 152 F. Supp. 343 (W.D. Wash. 1956), aff'd per curiam, 245 F.2d 955 (9th Cir. 1957).

${ }^{10}$ "In the recodification of the Uniform Code in 1956, supra note 12, the word "all" was deleted. See $70 A$ Stat. 37 , 10 U.S.C. \& 802(10) (1958).

${ }^{17}$ In the recodification of 1956 , the wording was modified to read: "Subject to any treaty or agreement ... or to any accepted rule of international law, persons serving with ...." 70A Stat. 37 , 10 U.S.C. \$ 802(II) (1958).

${ }^{18}$ In the 1956 recodification, immaterial changes were made in wording. $70 \mathrm{~A}$ Stat. 38 , 10 U.S.C. $\$ 802(12)(1958)$. The changes parallel those made in art. 2(11) of the Code. See note 17 supra.

${ }^{10}$ Recodified with immaterial changes of phraseology in $70 \mathrm{~A}$ Stat. 38 (1956), 10 U.S.C. $\S 803(a)(1958)$. 
(e) Article 4, which allows an officer dismissed by order of the President, and who thereby becomes a civilian, to request trial by general court-martial on the charges on which he was dismissed..$^{20}$

(f) Article I8, which provides that general courts-martial may "try any person who by the law of war is subject to trial by a military tribunal."21

(g) Article 48, which allows punishment of "any person" for contempt by up to thirty days confinement and fine of $\$ 100$ or both. ${ }^{22}$

(h) Article 104, which allows punishment of "any person" who aids the enemy in certain ways. ${ }^{23}$

(i) Article I06, which allows punishment of "any person who in time of war is found lurking as a spy or acting as a spy" under certain circumstances. ${ }^{24}$

\section{Applicable Constitutional Provisions}

The most apparent authorization for the enactment of the Uniform Code of Military Justice lies in article one, section eight, clause fourteen of the Constitution, wherein Congress is empowered "to make rules for

${ }^{20} 70$ A Stat. 38 (1956), 10 U.S.C. $\$ 804$ (1958).

${ }^{21}$ 70A Stat. 43 (1956), 10 U.S.C. § 818 (1958). There are three types of courtmartial-general, special, and summary. Only the general court-martial, which is presided over by a law officer, whose role parallels that of a civilian judge, can impose a sentence that entails more than six months of confinement or certain other punishments. See EVERETT, op. cit. supra note I, ch. 9 .

${ }^{22} 70$ A Stat. 53 (1956), 1o U.S.C. $\$ 848$ (1958). Probably sustainable by reason of the special rules applicable for trial either of "petty offenses" or of contempts. Supra note 9 .

${ }^{23}$ goA Stat 70 (1956), 10 U.S.C. $\S 904$ (1958). The only way to sustain this provision would be to view it as an exercise of congressional power to "define and punish . . . offenses against the law of nations," U.S. ConsT. art. I, § 8, cl. ro, in accord with the rationale of Ex parte Quirin, 317 U.S. I (1942). Interestingly, art. 104 of the Code contains no specific reference to "time of war"; but the term "enemy," as used in that article, would probably be taken to connote wartime. Of course, as the Korean hostilities made clear, there could be a serious question as to whether "war" requires a formal declaration of war. Cf. Weissman v. Metropolitan Life Ins. Co., II2 F. Supp. 420 (S.D. Cal. 1953); United States v. Shell, 7 U.S.C.M.A. 646, 23 C.M.R. I I0 (1957); United States v. Taylor, 4 U.S.C.M.A. 232, I5 C.M.R 232 (1954); United States v. Ayers, 4 U.S.C.M.A. 220, 15 C.M.R. 220 (1954); United States v. Gann, 3 U.S.C.M.A. I2, II C.M.R. I2 (1953); United States v. Bancroft, 3 U.S.C.M.A. 3, II C.M.R. 3 (1953); Langlas v. Iowa Life Ins. Co., 245 Iowa 713, 63 N.W.2d 885 (1954); Western Res. Life Ins. Co. v. Meadows, 152 Tex. 559, 26x S.W.2d 554, cert. denied, 347 U.S. 928 (1954). For an interesting contrast in approaches to the definition of "war," compare Lee v. Madigan, 358 U.S. 228 (1959), wit/ Ludecke v. Watkins, 335 U.S. 160 (1948). See also Woods v. Miller Co., 333 U.S. 138 (1948); Underhill, supra note $\mathrm{I}$, at $84-88$.

${ }^{24} 70$ A Stat. 7 1 (1956), ro U.S.C. $§ 906$ (1958). See also the discussion at note 23 supra. 
the government and regulation of the land and naval forces. ${ }^{25}$ Even without this mandate, however, it would seem quite supportable to sustain the enactment of a code and the establishment of a system of military justice under the legislative powers to "provide for the common defense,"26 "declare war," "raise and support armies,"28 and "provide and maintain a navy"28 —especially in light of the broad authorization for Congress "to make all laws which shall be necessary and proper for carrying into execution the foregoing powers, and all other powers vested by this Constitution in the government of the United States, or in any department or officer thereof." ${ }^{30}$ The last-quoted wording would sustain legislation necessary and proper for the execution of the President's "executive power"31 and his authority as "commander in chief of the army and navy."32

Article three of the Constitution vests the "judicial power" in courts whose judges shall have life tenure, ${ }^{33}$ extends this "power" to certain "cases" and "controversies,"34 and requires that "the trial of all crimes, except in cases of impeachment, shall be by jury; and such trial shall be held in the state where the said crimes shall have been committed; but when not committed within any state, the trial shall be at such place or places as the Congress may by law have directed."35 Clearly, this last provision envisages that some crimes against the United States could occur outside the boundaries of any American state, but how far this extraterritoriality was intended to extend is not specified. There have, however, been many cases involving crimes committed overseas. ${ }^{36}$

${ }^{25}$ See Ex parte Reed, I0o U.S. I3 (I879); Dynes v. Hoover, 6I U.S. (20 How.) $65(1857)$.

${ }^{20}$ U.S. Const. art. I, §s, cl. I.

${ }^{28} I d$. cl. Iz.

${ }^{27} \mathrm{Id}$. cl. I $\mathrm{I}$.

${ }^{29}$ Id. cl. $\times 3$.

${ }^{30} \mathrm{Id}$. cl. I8. Of course, the classic interpretation of the necessary and proper clause was by Chief Justice Marshall in McCulloch v. Maryland, 17 U.S. (4 Wheat.) $3 \times 5$ (1819).

${ }^{32}$ U.S. CONST. art. II, § $\mathrm{x}$.

${ }^{32} I d . \S 2$.

${ }^{33} I d$. art. III, \& I

${ }^{34} I d$. $\$ 2$. The "case and controversy" requirement for the exercise of judicial power-and as a prerequisite for federal jurisdiction-has been considered in such cases as Muskrat v. United States, $2 \times 9$ U.S. 346 ( IgIx), and Aetna Life Ins. Co. v. Haworth, 300 U.S. 227 (1937). At one time, it was considered that the real question in determining the validity of art. 3 (a) of the Code was whether "case," as used in the fifth amendment exception for "cases arising in the land or naval forces," had the saine technical meaning as when used in art. III, $\S_{2}$ of the Constitution.

${ }^{35}$ U.S. CONST. art. III, $§ 2$, cl. 2.

${ }^{30}$ See, e.g., United States v. Flores, 289 U.S. 137 (1933); Blackmer v. United States, 284 U.S. 42 I (1932); United States v. Bowman, 260 U.S. 94 (I922); Jones v. United States, 137 U.S. 202 (1890); United States v. Provoo, 215 F.2d 53 I (2d Cir. 
The fifth amendment of the Constitution states that "No person shall be held to answer for a capital, or otherwise infamous crime, unless on, a presentment or indictment of a grand jury, except in cases arising in the land or naval forces." Does "cases" here have the same technical meaning that it has been construed to have when used in article three to establish the "judicial power" over "cases" and "controversies"? ${ }^{37}$ Probably not-especially since the word seems to have a meaning of its own as used elsewhere in the fifth amendment in granting a privilege against self-incrimination. ${ }^{38}$ Another interesting question is why the founding fathers spoke of "land" and "naval forces" in the fifth amendment and in article one, section eight, clause fourteen; but at some other places used "army" and "navy."39 Was there an underlying concept that some persons might be members of the "land and naval forces," but not of either the army or the navy?

The sixth amendment of the Constitution, which guarantees trial by "an impartial jury of the state and district wherein the crime shall have been committed," contains no express exception like that in the fifth amendment. However, the same exception for courts-martial found in the fifth amendment has been read into this right of trial by jury. ${ }^{40}$

II

\section{Toth v. Quarles}

\section{A. Background of Article 3(a)}

As a prelude to examining Toth v. Quarles, ${ }^{41}$ which-at least partly ${ }^{42}$ -invalidated article $3(a)$ of the Uniform Code of Military Justice, it

1954); Best v. United States, I84 F.2d 131 (rst Cir.), cert. denied, 340 U.S. 939 ( I95I); United States v. Chandler, 72 F. Supp. 230 (D. Mass), aff'd, I 7 I F.2d 921 (Ist Cir.), cert. denied, 336 U.S. 918 (1949). Of course, the prosecution must be based upon some statute and it will apparently be presumed that the statute is not extraterritorial. American Banana Co. v. United Fruit Co., 213 U.S. 347 (1909); United States v. Cordova, 89 F. Supp. 298 (E.D.N.Y. 1950).

${ }^{37}$ See note 34 supra.

38 "[N] or shall be compelled in any criminal case to be a witness against himself." For leading cases relevant to the meaning of "case" in this context, see Ullman v. United States, 350 U.S. 422 (1956); Hale v. Henkel, zor U.S. 43 (1906); Brown v. Walker, I6I U.S. 591 ( 1896 ); Counselman v. Hitchcock, I42 U.S. 547 (1892).

${ }^{30}$ See U.S. CoNST. art. I, $\S 8$, cls. I2 \& $1_{3} ;$ art. II, $\$ 2$, all previously quoted in the text in pertinent parts.

${ }^{10}$ See Ex parte Milligan, 71 U.S. (4 Wall.) 2, 123, 138-39 (1866); Ex parte Quirin, 317 U.S. 1,40 (I942).

1350 U.S. II (1955).

42 To the effect that art. $3(\mathrm{a})$ of the Code is not completely dead and applies to one 
would be well to see how this provision became part of the Code in the first place. To a considerable extent, it represented congressional revulsion from the situation presented in Hirshberg v. Cooke, ${ }^{43}$ which concerned an enlisted man who had been a Japanese prisoner of war, and, after his liberation, was honorably discharged from the Navy on March 26, I946, because his original term of enlistment had expired. He was reenlisted in the Navy the following day, and about one year later, he was tried by court-martial on charges of maltreating other American prisoners of war while in Japanese captivity. The Supreme Court held-though not as a matter of constitutional interpretationthat crimes committed in one enlistment cannot be carried over as a basis for court-martial jurisdiction during a subsequent enlistment; and by this ruling, the defendant was virtually immunized from punishment for his misdeeds. Congress was also aware of a similar situation which concerned a WAC officer who, while on terminal leave, was apprehended by military authorities who wished to court-martial her for participating in the theft of the crown jewels of Hesse. ${ }^{44}$

Although these were the cases which particularly gave birth to article 3 (a) of the Code, ${ }^{45}$ there soon came to the public's attention another instance that seemed to demonstrate the need for legislative action. It was revealed in 1950-5I that two American OSS operatives, while on a mission in Italy, had apparently murdered one of their comrades and disposed of his body in a deep lake. Neither of these men, long out of the armed services, could be court-martialled under thenexisting law, nor did any American civil court have statutory authority to try them. After extradition failed, ${ }^{46}$ both of the accused were completely secure against punishment anywhere for their alleged misdeeda result that would be prevented under the wording of article $3(\mathrm{a})$.

\section{B. The Opinion of the Court}

Robert Toth had been an airman serving in Korea. After his discharge and return to civilian life, evidence was discovered which indi-

who committed a crime in a previous enlistment and then reenlisted in the armed services, see United States v. Gallagher, 7 U.S.C.M.A. 506, 22 C.M.R. 296 (1957).

336 U.S. 2 10 ( 1949 ).

4 Hironimus v. Durant, x68 F.2d 288 (4th Cir.), cert. denied, 335 U.S. 8 I 8 (1948) (military jurisdiction upheld).

${ }^{4}$ See Toth v. Quarles, 350 U.S. II, 26 (1955); United States v. Gallagher, 7 U.S.C.M.A. 506, 509, 22 C.M.R. 296, 299 (1957).

${ }^{40}$ In re Lo Dolce, ro6 F. Supp. 455 (W.D.N.Y. 1952). For the thwarting of another effort to punish the alleged. killers, see United States v. Icardi, 140 F. Supp. 383 (D.D.C. 1956) (prosecution for perjury in connection with testimony given about the slaying before a congressional committee). 
cated that he and two other men had collaborated in murdering a Korean. The other two men, both still in the Air Force when the crime was unearthed, were found guilty and sentenced by a court-martial to confinement. ${ }^{47}$ Since no American civil court, whether state or federal, had authority to punish a homicide in Korea, and since the punishment for murder is greater than five years' confinement, Toth fell squarely within the wording of article 3(a) of the Code, which has been heretofore quoted. The Supreme Court, reversing the Court of Appeals for the District of Columbia held, however, that this statute was invalid as applied to one who had been separated from the Air Force and had reverted to civilian life.

Although much of the discussion concerning the constitutionality of article 3 (a) of the Code had theretofore focused on the meaning of the fifth amendment's exception to the grand jury requirement, ${ }^{48}$ the opinion of the Supreme Court, written by Mr. Justice Black and joined in by five other Justices, centers on the lack of power under the Constitution to provide for any such trial of a person who has terminated all connection with the armed forces. While conceding that the Court had theretofore upheld military jurisdiction over a dishonorably discharged soldier who was a military prisoner serving the sentence of a prior courtmartial, the majority comments that "given its natural meaning, the power granted Congress 'to make rules' to regulate 'the land and naval forces' would seem to restrict court-martial jurisdiction to persons who are actually members or part of the armed forces."40 Of course, Mr. Justice Black does not specify who is a "part" of the armed forces but not a "member"; and, not surprisingly, the Government in later cases contended that this statement impliedly recognized an authority to court-martial civilian dependents and employees as a "part" of the armed forces. Be that as it may, the existence of this "natural meaning"

\footnotetext{
${ }^{47}$ United States v. Schreiber, 5 U.S.C.M.A. 602, 18 C.M.R. 226 (1955); United States v. Kinder, I4 C.M.R. 742 (1954).

${ }^{48}$ See, e.g., Morgan, Court-Martial Jurisdiction over Non-Military Persons under the Articles of War, 4 MinN. L. Rev. 79 (1920); Underhill, supra note I, at 89-90; Note, 67 HARv. L. Rev. 479 (1954). Moreover, the Court of Appeals for the District of Columbia also centered on this point in their opinion in the Toth case itself. Toth v. Quarles, 215 F.2d 22 (1954). But cf., Winthrop, Military LaW and Precedents 105-07 (I 920 Rep.).

${ }^{49} 350$ U.S. at 15 . The leading case upholding military jurisdiction over a military prisoner for offenses committed while in confinement but after discharge is Kahn v. Anderson, 255 U.S. I (1920). Cf. Ex parte Mason, 105 U.S. 696 (1881). It had been thought that the validity of military jurisdiction over the discharged prisoner might be tested in Lee v. Madigan, 358 U.S. 228 (1959); but the case was disposed of on another ground.
} 
is rather surprising, since it does not seem to have been clearly glimpsed by many of the persons most concerned with military jurisprudence..$^{50}$ Moreover, could it not be reasoned that the "rule" being promulgated by Congress was, "Thou shalt not kill," that Toth had violated that "rule" while a serviceman, and that article one, section eight, clause eighteen of the Constitution sustained article $3(a)$ of the Code as a "necessary and proper" means for punishing violation of that norm in the future? Under this hypothesis, the real issue would center not on power, but on whether article three, section two of the Constitution, and the fifth and sixth amendments limited the use of courts-martial in this situation.

The majority supported its "plain meaning" interpretation of article 3 (a) of the Code by noting that "any expansion of court-martial jurisdiction like that in the 1950 Act necessarily encroaches on the jurisdiction of article three of the Constitution where persons on trial are surrounded with more constitutional safeguards than in military tribunals." To 1 be sure, as a prerequisite for the invocation of article 3(a) of the Code, there must be no state or federal court that can consider the offense; and so it could be contended that necessarily there would be no encroachment on civil jurisdiction. The majority's answer clearly would be, however, that Congress could enact legislation to make the crimes of ex-servicemen punishable in the federal courts; and, therefore, article 3 (a) really encroaches on a jurisdiction with which the civil courts could be entrusted.

Where, however, as in the Toth case itself, a crime committed overseas is involved, the expansion of federal civil court jurisdiction presents some major problems. ${ }^{52}$ For instance, how and from whom will the grand jury and petty jury be selected? Certainly it will be impossible to fulfill the goal of the sixth amendment that the accused be tried "by an impartial jury of the state and district wherein the crime shall have been committed." In In both federal civil courts and in courts-martial, the prosecution and accused each has the benefit of the subpoena power,

\footnotetext{
${ }^{50}$ See note 48 supra.

81350 U.S. at 15.

${ }^{52}$ See EVERETT, op. cit. supra note $\mathrm{I}$, at 33 .

${ }^{53}$ Discussed by the majority in the Toth case. 350 U.S. at I6. Of course, as heretofore noted, art. III, $\S_{2}$ of the Constitution does contemplate that some cases will arise overseas, but that the jury will be selected in the United States.

${ }^{54}$ See Uniform Code of Military Justice arts. $46 \& 47,70 A$ Stat. 53 (1956), I0 U.S.C. $\$ \S 846,847(1958)$. Concerning the availability of subpoenas for an accused in a court-martial, see Everett, The Role of the Deposition in Military Justice, MILITARY L. REV. 131, I36 (Dep't of Army Pamphlet 27-100-7, 1960).
} 
but this is of little avail if the witness to be subpoenaed resides in a foreign land and the court is sitting in the United States. ${ }^{55}$ It is questionable whether a federal district court has, or could permissibly be given, any authority to hold sessions overseas, where the witnesses would generally be more available and where local conditions could be observed by the trier of fact. Even if permissible to do so, the transporting of federal district judge and jury overseas does not seem feasible. On the other hand, a court-martial can permissibly and readily be convened anywhere in the world. ${ }^{.6}$

The Court emphasized the dangers lurking in military trials and the advantages of a trial in federal civil courts-among them, the independence provided by article three of the Constitution for federal judges, who, unlike many state court jurists, enjoy life tenure, and the requirements of indictment by grand jury and trial by a petty jury chosen from all walks of life. Under article $3(\mathrm{a})$ of the Code, if upheld, millions of veterans would remain indefinitely subject to the risk of trial by court-martial and to the accompanying deprivation of important procedural safeguards. The risk would be heightened because, under the Uniform Code, the prescribing of maximum limits on punishment is left mostly to the President; ${ }^{57}$ therefore, the five-year-confinement limitation on the applicability of article $3(a)$ would mean little if there were a strong purpose to bring veterans within military jurisdiction. For instance, a one day's absence without leave in a combat zone is sometimes punishable by life imprisonment, and yet is not triable in either state or federal civil courts; therefore, under the Uniform Code an ex-serviceman accused of this offense would always be subject to trial by court-martial.

Despite a stated recognition of the importance of military discipline, the majority concluded in the Toth case that the effort to court-martial a civilian for offenses committed while on military duty is beyond Congress' constitutional power, which is limited to "the least possible power

\footnotetext{
${ }^{55}$ American citizens overseas can sometimes be compelled to testify. Blackmer v. United States, 284 U.S. 42 I (1932).

${ }^{50}$ The convening of the court-martial overseas is subject to the express or implied consent of the foreign government where it proposes to hold its sessions. Frequently, either by reason of a treaty or as a matter of comity, the foreign government will not only consent to the holding of the courts-martial, but will also aid the court-martial to obtain testimony. See Snee \& Pye, Status of Forces Agreement: Criminal JurisDICTION 94-IOI (1957).

${ }^{\text {g7 }}$ See U.S. Dep'T of Defense, Manual for Courts-Martiad, United States (1951).
} 
adequate to the end proposed."\$s The circumstance that several other countries, among them Great Britain, Canada, Australia, and New Zealand, have enacted measures similar to article 3(a) of the Code was deemed unimpressive, since those countries lack our Bill of Rights, "and we are not willing to hold that power to circumvent those safeguards should be inferred through the Necessary and Proper Clause." ${ }^{39}$

Clearly the test of the "least possible power adequate to the end proposed" differs in emphasis from Chief Justice Marshall's timehonored pronouncement in McCulloch v. Maryland concerning the necessary and proper clause that "where the law is not prohibited, and is really calculated to effect any of the objects entrusted to the government, to undertake here to inquire into the degree of its necessity, would be to pass the line which circumscribes the judicial department, and to tread on legislative ground." Even where there is applied only the test stated by the Court, however, some doubt remains as to the correct outcome. Presumably the "end proposed" by article 3(a), as well as the other articles of the Uniform Code, is the maintenance of discipline in the armed services and, as a corollary, the punishment of infractions of discipline. Such a goal is certainly legitimate. Also, it is clear that in disorganized combat areas, and even elsewhere, an offense may not come to light for several years-as was true in the instance of the OSS slaying in northern Italy. The prospect that an offense, if committed, may not soon be discovered is certainly one incentive to commit the crime. This incentive is enhanced when it becomes apparent that in the event discovery is retarded, prosecution will be difficult, if not impossible. Consequently, the significant question would seem to be whether the Supreme Court did suggest a feasible alternative when it proposed that trial of ex-servicemen be committed to the federal district courts, rather than to courts-martial. Of course, the practical difficulties, hereinbefore discussed, that may accompany the civil court trial of a veteran like Toth, whose suspected offense occurred overseas, bear heavily on such feasibility. Moreover, in light of the antimilitaristic tradition of some

${ }^{58} 350$ U.S. at 23. The Court cited Anderson v. Dunn, 19 U.S. (6 Wheat. 204) 230 , $23 \times(1821)$.

60 350 U.S. at 22. For the foreign laws concerned, see the dissent of Justice Reed, id. at 30 .

${ }_{17}$ U.S. ( 4 Wheat.) 316,423 (18 19). Another well-known constitutional formula is in these terms: "Let the end be legitimate, let it be within the scope of the constitution, and all means which are appropriate, which are plainly adapted to that end, which are not prohibited, but consist with the letter and spirit of the constitution, are constitutional." Id. at $42 \mathrm{I}$. 
of the foreign countries whose military law parallels article $3(a)$ of the Code, ${ }^{61}$ it seems highly relevant to feasibility that these countries felt compelled to restrict trial by jury by providing for the court-martial of ex-servicemen.

In a footnote to its opinion, the Court commented that the fifth amendment "does not grant court-martial power to Congress; it merely makes clear that there need be no indictment for such military offenses as Congress can authorize military tribunals to try under its Article I power to make rules to govern the armed forces. ${ }^{362}$ It is indisputable that the Bill of Rights, which purports to limit governmental authority, cannot be used directly as a source of congressional power. However, the Supreme Court has noted that "the first ten amendments and the original Constitution were substantially contemporaneous and should be construed in pari materia." ${ }^{33}$ Under this approach, the wording of the fifth amendment exception to the grand jury safeguard would seem to be a valid aid to the construction of the power "to make rules" for the "land and naval forces," so that congressional power under article one, section eight, clause fourteen of the Constitution would then be coextensive with "cases arising in the land or naval forces." In that event, it would be necessary to determine the meaning of the last-quoted wording.

In this same connection it should be recalled that one announced reason for a narrow construction of military jurisdiction here was to avoid circumvention of the Bill of Rights. If the wording of the exception in the fifth amendment for "cases arising in the land or naval forces" should itself properly be interpreted as excluding from the grand jury safeguard ${ }^{64}$ a crime committed by a serviceman, regardless of his later status, it could be argued that there was little reason to adopt a narrow construction of congressional power in order to impose judicially a limitation that the founding fathers had declined to impose when they drafted the fifth amendment.

\section{The Dissenting Opinion}

Justice Reed, joined by Justices Minton and Burton, dissented forcefully. In support of his contention that Congress possessed a long-

${ }^{01}$ The English tradition in this regard was adverted to in Caldwell v. Parker, 252 U.S. 376,382 ( 1920$)$.

62350 U.S. at 14 n.5.

${ }^{63}$ Patton v. United States, 28 I U.S. 276,298 (1930).

${ }^{64}$ And indirectly also from the safeguard of trial by jury. See cases cited at note 40 supra. 
recognized power to enact legislation like article 3(a) of the Code, he cited precedents upholding as constitutional a statute originally enacted in I 863 and purporting to reserve military jurisdiction over ex-servicemen in certain fraud cases. ${ }^{65}$ In so far as the fifth amendment exception for "cases arising in the land or naval forces" is concerned, Justice Reed considered that the word "case" did not refer to litigation, here the commencement of prosecution (which, of course, occurred after Toth had become a civilian), but instead it signified a series of events that constituted an offense (and the facts that constituted the alleged murder had all existed prior to Toth's discharge so that he would have been subject to court-martial if these facts had then been known to military authorities). ${ }^{66}$

Justice Reed noted that even though Toth had become a civilian, ${ }^{67}$ there was no doubt that he was a serviceman at the time of the alleged crime. Therefore, no problem was presented of bringing new civilians within the field of military authority in so far as the promulgation of rules of conduct was concerned. The only issue concerned the procedure for punishing violations of those rules. As a precedent for military jurisdiction over this civilian, the dissent cited the precedents allowing court-martial of a draftee who has not reported for induction as ordered, and who is, therefore, in one sense still a civilian. ${ }^{68}$

${ }^{05} 350$ U.S. at $32-34$. The statute, carried forward later into the Articles of War and the Articles for the Government of the Navy, was 12 Stat. 696 ( 1863 ). Among the decisions upholding this statute are Kronberg v. Hale, I8o F.2d 128 (gth Cir.), cert. denied, 339 U.S. 969 (1950); Ex parte Joly, 290 Fed. 358 (S.D.N.Y. 1922); Terry v. United States, 2 F. Supp. 962 (W.D. Wash. 1933); In re Bogart, 3 Fed, Cas. 796 (No. 1,596) (C.C. Cal. 1873 ).

${ }^{\circ 0} 350$ U.S. at 39. Justice Reed drew an analogy to United States v. Bevans, i 6 U.S. ( 3 Wheat.) 336,388 ( 1818 ) ("the waters on which . . cases may arise"); Waring v. Clarke, U.S. (5 How.) 441, 466-67 (1847) ("cause of action arisen on the ocean"). The opposing position would gain strong support from art. III, $\$ 2$, which refers to "all cases, in law and equity, arising under this Constitution ....." See note 34 supra.

${ }^{07}$ However, note that Justices Burton and Minton, in a separate dissenting opinion, take the position that Toth had only a "conditional discharge" and was not "a fullfledged civilian." 350 U.S. at 44 .

${ }^{88} I d$. at 32. See Arver v. United States, 245 U.S. 366 (1917). With respect to World War II inductees, it was held that military jurisdiction did not attach until actual induction had taken place as provided for by Selective Service Regulations. Billings v. Truesdell, 321 U.S. 542 (1944). However, the result was not in any way rested on constitutional grounds; and apparently the court still considered that it would be constitutional to treat as subject to military jurisdiction persons who had been ordered to report for induction and be inducted, but who had for some reason failed to do so. $I d$, at 556 . 


\section{Some General Observations}

Most of the objections to civil court trial of ex-servicemen like Toth center on the situation where the crime occurs abroad. Accordingly, as a matter of legislative draftsmanship, it might have been wise if, at the time the Uniform Code was first adopted, jurisdiction under article 3(a) had been limited (a) to persons still in the armed forces under a reenlistment, ${ }^{69}$ and (b) to persons who are now civilians but who committed major crimes while they were in the armed forces and outside the United States and its territories.

In such instances, even while acknowledging the importance of the tradition of trial by a local jury, one can properly emphasize that any such trial is an impossibility and that necessarily, if tried in a civil court, the case will be determined by persons who are not from the area where the crime took place and who may, therefore, be unaware of important circumstances. Moreover, where the crime occurred overseas, there might be considerable expense and difficulty in getting witnesses, especially foreign witnesses, to come to the United States to testify in a federal district court; and disruption in military operations might be produced by bringing military witnesses back from overseas to testify.

In such situations of undiscovered crime overseas, the only real alternatives often will be extradition to the foreign country for trial, or simply no punishment at all. Extradition will, of course, hinge on the wording of the extradition treaty and the desire of the foreign government to prosecute. When it is obtained, the ironic result will be that the accused is subjected to foreign trial-often lacking in many of the safeguards that are provided for courts-martial by the Uniform Code of Military Justice-because of a doctrinaire insistence on protecting him from a remote military despotism. Should extradition fail and trial in a federal civil court prove impossible, the result will occasionally be not only a windfall for the ex-serviceman, but also a discrimination against fellow criminals whose crimes were discovered prior to their discharge. ${ }^{70}$

${ }^{80}$ This was the situation involved in United States ex rel. Hirshberg v. Cooke, 336 U.S. 210 ( 1949 ), and in United States v. Gallagher, 7 U.S.C.M.A. 506, 22 C.M.R. 296 (1957). See also United States v. Estrada, 18 C.M.R. 872 (1955); United States v. Owens, 6 C.M.R. 691 (1952).

${ }^{70}$ This was the case with Toth, his two comrades, who were still in the Air Force, having been tried by court-martial. Of course, in many instances, the man in uniform occupies an especially precarious position. For example, if a serviceman steals property within the United States, he can be prosecuted by a state court for the offense as well as by a court-martial. There is no double jeopardy, because the tribunals draw their authority from different sources. See EVERETT, op. cit. supra note I, at 38-40. A civilian committing the same crime in the same place and in collaboration with the serviceman 
With respect to dangers of trial by court-martial, it would seem that the majority exaggerated them considerably as a forensic device to uphold the decision. Certainly, the reader of the Court's opinion would hardly recognize military justice as the same system referred to in some other recent Supreme Court opinions. ${ }^{71}$ Might not the best solution have been to uphold military jurisdiction over Toth, but to apply a broader standard of review to all trials by court-martial-whether of ex-servicemen like Toth or persons still in uniform? ? $^{72}$ Moreover, the risks under article $3(\mathrm{a})$ of the Code seem to pale into insignificance alongside those created by the Quirin case, which allows American citizens to be tried before ad hoc military commissions-subject neither to the requirements of the Bill of Rights nor to those of the Uniform Code of Military

could only be punished in a state court, since he would not be subject to military justice and no crime cognizable by a federal district court has been committed. The same double exposure of a serviceman to punishment will exist in some foreign countries where he may be stationed. Id. at 46 .

${ }^{71}$ See, e.g., the comment of the original majority in Kinsella v. Krueger, 351 U.S. 470,474 (1956), that, "The Code was carefully drawn by Congress to include the fundamental guarantees of due process, and in operation it has provided a fair and enlightened system of Justice,"; and of Judge Latimer in United States v. Burney, 6 U.S.C.M.A. 776, 796, 2 1 C.M.R. 98, 118 (1956). How fair then is military justice today? Among its disadvantages are the possibilities that a commanding officer may control or influence the deliberations of the court-martial; the failure to insure the competency and independence of the "trial judge" (although immense strides forward are being made in this regard); the vagueness in some provisions of substantive military law, see Everett, Article 134 , Uniform Code of Military Justice-A Study in Vagueness, 37 N.C.L. REv. I42 (1959); the occasional bypassing of courtroom safeguards by use of administrative procedures; the relative lack of safeguards for the summary or special court-martial; the limited scope of the right of confrontation, see Everett, The Role of the Deposition in Military Justice, MiliTARY L. REv. I3 I (Dep't of Army Pamphlet No. 27-100-7, I 960); occasionally harsh substantive rules and sentences; and occasionally less than proficient trial and defense counsel (a situation that has also vastly improved in recent years). It must always be remembered, however, that there is another side to the ledger. The advantages granted an accused under today's system of military justice include: warning against self-incrimination before any interrogation is commenced; free counsel for the accused during the formal pretrial investigation required for serious offenses and during the trial itself; liberal rules as to mental responsibility and as to some substantive matters; liberal rules for the review of courts-martial; a free copy of the record of trial; no costs to the accused for appeal of a case; free appellate defense counsel; review of the appropriateness of the sentence as well as of the facts and law. Compare Walsh, Return to Drumhead Justice? 42 A.B.A.J. 521 (1957), with Hamilton, Drumhead Justice is Dead!, 43 A.B.A.J. 797 (1957).

${ }^{72}$ Concerning the present standard for review of courts-martial by civil courts, see Burns v. Wilson, 346 U.S. I37 (1953). But cf., Whelchel v. McDonald, 340 U.S. 122 (1950). See also Jackson v. Taylor, 353 U.S. 569 (1957). At the present time, courts-martial are more insulated than state courts from review by federal civil courts. See EVERETT, op. cit. stupra note $I$, at 313 . 
Justice-for alleged violations of the amorphous, largely nonstatutory law of war.

\section{III}

\section{American Civilians Abroad-the i956 Version}

\section{A. Factual Background}

In June 1956, the Supreme Court handed down the short-lived opinions in Kinsella v. Krueger ${ }^{73}$ and Reid v. Covert, ${ }^{74}$ which concerned the status of two ladies who, while overseas and in alien territoryone in Japan and the other in Great Britain, -had slain their respective spouses, who were then members of the armed services. The Covert case involved the added problem that the accused's conviction had been reversed by the Court of Military Appeals because of error in the treatment of her sanity defense, ${ }^{75}$ and a rehearing had been ordered, which was scheduled to take place in the United States at Bolling Air Force Base, rather than overseas. Although each accused had been tried for and convicted of premeditated murder, each had received only a life sentence for the crime. ${ }^{76}$ Writs of habeas corpus had been sought to obtain the release of each defendant. ${ }^{77}$

\section{B. The Government's Position}

\section{Power under article one, section eight, clause fourteen}

The Government counsel fired two barrels in defense of military jurisdiction-one loaded with ammunition provided by article one, section eight, clause fourteen, which authorizes Congress "to make rules" for the "land and naval forces," and the other with that obtained from an assumed authority to regulate foreign affairs. As to the former, it was urged that civilian dependents came within the purview of the "land and naval forces," and that article 2(II) of the Uniform Code represented merely the exercise of congressional power specifically entrusted by the Constitution.

This interpretation was substantiated by several previous Supreme

\footnotetext{
${ }^{73} 35$ I U.S. 470 (1956).

${ }^{74} 35$ I U.S. 487 (1956).

${ }^{75}$ United States v. Covert, 6 U.S.C.M.A. 48 , 19 C.M.R. 174 (1955).

${ }^{76}$ At the rehearing, under the Uniform Code, the court-martial could not have imposed a sentence more severe than at the original trial. See Uniform Code of Military Justice $\S 63(\mathrm{~b}), 70 A$ Stat. 58 (1956), ro U.S.C. $\$ 86_{3}$ (b) (1958).

${ }^{77}$ See United States v. Kinsella, 137 F. Supp. 806 (S.D.W. Va. 1956); Reid v. Covert 35 I U.S. 487,488 (1956).
} 
Court pronouncements. For instance, as early as the landmark case of Ex parte Milligan, it had been commented: $:^{78}$

The discipline necessary to the efficiency of the army and navy, required other and swifter modes of trial than are furnished by the common law courts; and, in pursuance of the power conferred by the Constitution, Congress has declared the kinds of trial and the manner in which they shall be conducted, for offences committed while the party is in the military or naval service. Every one connected with these branches of the public service is amenable to the jurisdiction which Congress has created for their government, and, while thus serving, surrenders his right to be tried by the civil courts.

In Duncan v. Kahanamoku, the opinion of the Court, written by Justice Black, spoke of a "well-established power of the military to exercise jurisdiction over members of the armed forces [and] those directly connected with such forces . . .." Es Especially in point was Madsen v. Kinsella, ${ }^{80}$ which some commentators had deemed to have settled that jurisdiction exists to court-martial any civilian dependents overseas. ${ }^{81}$ In fact, Mrs. Madsen claimed that a military government court lacked jurisdiction to try her because she fell within the jurisdiction of a court-martial. A close reading of the opinion there seems clearly to indicate that the Court accepted her contention that she was subject to court-martial, but reasoned that this jurisdiction was concurrent with, not exclusive of, the jurisdiction of military government courts established by American military authorities to dispense justice in occupied Germany. ${ }^{82}$ The remark by the Court in the Toth case concerning persons "who are actually members or part of the armed forces" was also seized upon by the Government to support its interpretation. ${ }^{83}$

- Various lower court precedents were cited that upheld military jurisdiction over various civilians who were "in the field" with the armed forces ${ }^{84}$ and thus could be viewed as sustaining an hypothesis

\footnotetext{
${ }^{78} 7$ I U.S. (4 Wall.) 2, 123 (1866). (Emphasis added.)

71327 U.S. 304,313 (1946). (Emphasis added.)

${ }^{50} 343$ U.S. 341 (1952).

${ }^{81}$ AYCOCK \& WURFEL, op. cit. supra note 15 , at 60-61.

:2 See the discussion of the Madsen case in United States v. Burney, 6 U.S.C.M.A. 776, 793, 21 C.M.R. 98, II 5 (1956).

${ }_{83} 350$ U.S. at 15 . (Emphasis added.) Also tending to uphold jurisdiction were the rulings of the Supreme Court that discharged military prisoners could be courtmartialed, as well as persons who had been ordered to report for induction but had failed to do so. Supra notes 49,68 .

${ }^{86}$ See, e.g., Hines v. Mikell, 259 Fed. 28 (4th Cir. 1919); Ex parte Jochen, 257
} 
that some civilians fall within the purview of the "land and naval forces." For the most part, these cases concerned employees, rather than dependents, but government counsel did call attention to historical materials indicating that in both the British and American armies around the time of the American Revolution, some women accompanying the armed forces had been court-martialed. ${ }^{85}$

Unlike Toth, the two civilian dependents did have a close connection with the armed forces both at the time of the offense and at the time of trial. They were transported overseas at government expense; they went overseas with special passports that reflected their status as dependents of military personnel; they received special commissary, post exchange, housing, postal, and currency privileges; and so on. In the minds of the populaces in the countries to which these two spouses had accompanied their husbands, they were closely identified with the American armed forces.

Furthermore, according to the Government, the necessities of the situation should help sustain an interpretation of article one, section eight, clause fourteen of the Constitution that would include in the "Iand and naval forces" civilian dependents who accompanied their husbands overseas. In countries like Germany-a land where, according to the Government, there were recently well over I50,000 American military dependents-the problems of maintaining discipline would be exacerbated if court-martial jurisdiction were lacking. A civilian can do equally as much harm as someone in uniform if, while overseas, he kills, peddles narcotics, smuggles, spies, or neglects security regula-

Fed. 200 (S.D. Tex. 1919); Ex parte Falls, 251 Fed. 415 (D.N.J. 1918); Ex parte Gerlach, 247 Fed. 616 (S.D.N.Y. 1917). These decisions were cited by the Supreme Court with apparent approval in Duncan v. Kahanamoku, 327 U.S. 304, 313 n.7 (1946). And Ex parte Jochen, supra, at 204, states specifically: "That it is not necessary that a person be in uniform in order to be a part of the land forces, I think clear, not only upon considerations of common sense and common judgment, but upon wellconsidered and adjudicated authority."

${ }^{85}$ No effort will be made here to summarize the voluminous historical material that was presented to the Court by the briefs on both sides. The Government relied heavily on some of the instances during the American Revolution of court-martial of women accompanying the armed forces, as recited in BLUMENTHAL, WOMAN CAMP FOLLOWERS OF THE AMERICAN REvolution (1952). The relation of women to the armed forces at that time is felicitously described by Blumenthal in these terms: "British camp women in the Revolution were an established institution. It was the tradition that men-at-arms needed women-at-arms. Nor did the Revolution end the British tradition." Id. at 53 . It might be suggested that, for American forces stationed overseas today, the importance to their morale of having the companionship of their families is as great as was the importance of the "camp women" to the morale of the British troops in the Revolution. 
tions. Such harm can be direct, or it can be indirect-for example, through the creation of an international incident. ${ }^{86}$

\section{Powers outside the United States}

In Missouri v. Holland, ${ }^{87}$ the Supreme Court, in ruling on a statute that had been passed to execute a treaty with England and that was being assailed as an interference with the rights reserved to the states by the tenth amendment, commented that "Acts of Congress are the supreme law of the land only when made in pursuance of the Constitution, while Treaties are declared to be so when made under the authority of the United States." This statement has aroused considerable apprehension in some persons because of its interpretation by them as meaning that, subject perhaps to specific limitations like those of the Bill of Rights, ${ }^{88}$ Congress can enact any laws so long as they can be brought under the umbrella of some treaty.

If article 2(II) of the Uniform Code of Military Justice could be linked to the execution of some treaty, government counsel hoped that it could be sustained, even if it were deemed by the Supreme Court to fall outside the congressional powers granted by article one, section eight, clause fourteen of the Constitution. Furthermore, there are some indications that an administrative agreement or other international compact not falling within the precise definition of a "treaty" would suffice to provide legislative power. ${ }^{89}$

Today, a multilateral treaty, the NATO Status of Forces Agreement, does govern the relationship of American military jurisdiction to the authority of several of the "receiving states" wherein our forces are located. ${ }^{90}$ At the time of the two uxoricides with which the Supreme Court was concerned, however, the relationship was controlled by administrative agreements of the United States with Great Britain and with Japan. ${ }^{91}$ The circumstance that article 2(II) of the Code preceded the agreement with Japan made it difficult to view the agreement

\footnotetext{
${ }^{80}$ An exceptionally good discussion of this whole problem is contained in the opinion of Judge Latimer in United States v. Burney, 6 U.S.C.M.A. 776, 21 C.M.R. 98 ( 1956$)$, a copy of which opinion was filed as an appendix to one of the Government briefs.

${ }_{87}{ }_{252}$ U.S. 416 (1920).

${ }^{88}$ Cf. Asakura v. Seattle, 265 U.S. 332 (1924).

${ }^{80}$ Cf. United States v. Pink, 31 5 U.S. 203 (1942); United States v. Belmont, 301 U.S. 324 (1937).

${ }^{\circ}$ TIAS 2846. For a comprehensive discussion of this treaty, see SNEE \& PYE, $O p$. cit. supra note 56. See also Note, 70 HARv. L. REv. 1043 (1957).

${ }^{\circ 1}$ See Reid v. Covert, 354 U.S. 1, 15-16 (1957).
} 
as authorizing that provision of the Uniform Code. Moreover, the initial wording of article 2 (II) - "subject to the provisions of any treaty or agreement"-is not calculated to convince one that the treaty-making power can sustain this military jurisdiction. Most important, there has been no showing that either in drafting article 2(II) of the Code or in negotiating any international arrangement, anyone intended to use the power to make treaties and international agreements as a springboard for creating military jurisdiction of American military civilians overseas. ${ }^{92}$

Another, and rather shadowy, area of authority exists as to international affairs, however, from which government counsel also sought to derive support. In United States v. Curtiss-Wright, ${ }^{03}$ the Supreme Court was called upon to consider authority delegated to the President by Congress to halt certain shipments of arms overseas. The Court first noted that the defendant's objection of unlawful delegation might have more weight if the delegation related to internal, rather than external and foreign, affairs. Then, it was emphasized that with respect to internal affairs, the federal government can exercise no powers except those specifically enumerated in the Constitution or those implied therefrom as necessary and proper. The primary purpose of the Constitution was to carve from the general mass of legislative powers then possessed by the states those that it was thought desirable to vest in the federal government, and the rest, those not enumerated in the Constitution, were left with the states. This carving out applied only to powers that the states then had; not, however, to powers that already were in the federal government because of a transfer of external sovereignty from the Crown.

The upshot of this reasoning was the Court's conclusion that certain powers, such as those to declare war, conclude peace, make treaties, and maintain diplomatic relations, would repose in the United States as an attribute of its national sovereignty-even if those powers were never mentioned in the Constitution. The Court gave various examples of powers possessed by the United States simply because it is a member of the family of nations, and without which it would not be completely

\footnotetext{
${ }^{92}$ Cf. SNEE \& PYE, op. cit. supra note 56, at 7-40. Actually, the American negotiators undoubtedly assumed that they already possessed this jurisdiction under the Uniform Code, and, therefore, they had no occasion to consider the use of a treaty to create this jurisdiction. Instead, they were seeking to induce the "receiving states" to consent of the exercise of American jurisdiction aud to waive their own territorial jurisdiction over the Americans stationed within their boundaries.

${ }^{83} 299$ U.S. 304 (1936).
} 
sovereign. In so far as the role of the President was concerned, the Supreme Court concluded that his special responsibilities in the field of foreign affairs justify an extra leeway for Congress to delegate authority to him. ${ }^{94}$

Government counsel considered that the Curtiss-Wright case was ample precedent for the Court to hold now that military jurisdiction over American dependents accompanying the armed forces overseas did not have to be linked to any specific constitutional power. Instead, it could be rested on some concept of "sovereignty" and on the premise that an entirely different technique for ascertaining congressional and presidential power should be utilized where external affairs are involved. Incidentally, since Toth's alleged offense concerned what might be considered American "external affairs"-the killing of a Korean by an American airman while he was in Korea-the same reasoning might even have been advanced in support of military jurisdiction over him.

\section{The Opinion of the Court}

The original opinion of the Court, delivered in 1956, was written by Justice Clark: and concurred in by Justices Reed, Minton, Burton, and Harlan. The majority found it unnecessary to consider whether article 2(II) of the Code could be sustained under article one, section eight, clause fourteen of the Constitution. Instead, they noted that it had been long recognized that Congress "may establish legislative courts outside the territorial limits of the United States proper."195 Moreover, in cases arising in Hawaii, the Philippines, and Puerto Rico, the Court had affrmed the power of Congress to provide a system of justice that did not include trial by jury. ${ }^{96}$ Great reliance was also placed on the rather old case of In re Ross, ${ }^{97}$ which upheld the jurisdiction of an American consular court in Yokohoma to convict an American seaman of an offense committed in Japan. Although the United States has now relinquished all of its extraterritorial rights in any foreign country, the Court considered that the jurisdiction of the consular courts fur-

${ }^{94}$ Cf. Chicago \& Southern Air Lines v. Waterman S.S. Corp., 333 U.S. 103 (1948).

${ }^{96}$ Kinsella v. Krueger, $35 \mathrm{x}$ U.S. 470, 475 (1956).

${ }^{\circ 0}$ Balzac v. Porto Rico, 258 U.S. 298 (1922); Hawaii v. Mankichi, 190 U.S. 197 (1903); and Dorr v. United States, 195 U.S. 138 (1904). As to these legislative courts, see also the leading case of American 1ns. Co. v. 356 Bales of Cotton, 26 U.S. (i Pet.) $511(1828)$.

${ }^{07}{ }_{140}$ U.S. 453 ( $\left.189 \mathrm{I}\right)$. The consular court whose jurisdiction was challenged in this case had been established pursuant to a treaty between the United States and Japan. The Ross case was cited with approval in Ex parte Bakelite Corp., 279 U.S. 438, 45 I (1929). 
nished an apt analogy for court-martial jurisdiction of civilian dependents overseas. The Ross case, together with the cases involving jurisdiction over American territories, was held to "establish beyond question that the Constitution does not require trial before an Article III court in a foreign country for offenses committed there by an American citizen and that Congress may establish legislative courts for this purpose." 108

In so far as the cases concerning trials in Hawaii, the Philippines and Puerto Rico are concerned, it can be seen that they are readily distinguishable since, under article four, section three of the Constitution, Congress does have express "power to dispose of and make all needful rules and regulations respecting the territory or other property belonging to the United States." Thus, as to persons in those geographic areas, Congress did have some authority to proceed merely because of the relationship of those areas to the United States. For example, no one could question the power of Congress to enact a substantive criminal code for those areas, even if-by reason of article three of the Constitution and the Bill of Rights-some question might be raised concerning the type of procedure that could be created to enforce that substantive code.

On the other hand, if civilian dependents overseas are not within the "land and naval forces" under article one, section eight, clause fourteen of the Constitution, a question can properly be raised about the power of Congress even to enact a substantive code of conduct for these individuals. In general, federal criminal jurisdiction has been exercised territorially, although there have been various prosecutions for offenses committed overseas and some dicta claiming American authority to punish American citizens for crimes committed anywhere in the world. ${ }^{00}$ Nonetheless, if an effort were made to prosecute an American

\footnotetext{
${ }^{93}$ Kinsella v. Krueger, 351 U.S. 470, 476 (1956).

${ }^{\circ 1}$ See, e.g., Skiriotes v. Florida, 313 U.S. 69, 73 (1941), stating that ". . . the United States is not debarred by any rule of international law from governing the conduct of its own citizens upon the high seas or even in foreign countries when the rights of other nations or their nationals are not infringed." This same statemement is quoted in Lauritzen v. Larsen, 345 U.S. 571,587 (1953). In light of their context and the precedents cited in their support, it is quite possible that the Court had in mind a situation like that in Bowman v. United States, 260 U.S. 94 ( 1922 ), where a rather direct effect on governmental operations was present. For further consideration of extraterritoriality, see Brierly, The Law of Nations 231-36 (5th ed. 1955); Brewster, ANTITrust AND AMERICAN Business ABroad (1958). In the last-cited text, reliance is placed on the Ross case as supporting extraterritorial jurisdiction. However, in light of the ill fate of the Ross case in recent times, as described hereinafter in greater detail, this reliance may be misplaced. In Wilson v. Girard, 354 U.S. 524 (1957), the Supreme Court was called upon to consider an administrative agreement between the Unitcd
} 
tourist in a federal district court for a homicide allegedly committed in England or Japan-and assuming a federal statute specifically authorized such prosecution-there would certainly be a permissible question as to the constitutional basis for such a trial. Would it rest on the "attributeof-sovereignty" approach taken in the Curtiss-Wright case? Or on what? If the federal government is a government of express powers and there is no express power to deal with foreign homicides by American citizens, does it not follow that such homicides should be deemed beyond the powers of our government to punish? To go one step further, if civilian dependents overseas are not part of the "land and naval forces" within the meaning of article one, section eight, clause fourteen of the Constitution, as properly interpreted, should they not be treated for purposes of the present analysis exactly like tourists overseas?

In the Ross case, the offender had not committed his crime in an American territory-although apparently on an American ship-and so the right to try him could not be grounded on article four, section three

States and Japan wherein provision was made concerning criminal jurisdiction over American military personnel in Japan. Girard, an American soldier, had shot and killed a Japanese national. In discussing this homicide, the Court remarked: "A sovereign nation has exclusive jurisdiction to punish offenses against its laws committed within its borders unless it expressly or impliedly consents to surrender its jurisdiction." Id. at 529. This statement is subject to several interpretations. If it be taken to mean that a nation can punish only crimes "against its laws," the court has done little more than state a truism; even when the laws of another sovereignty are made the basis of punishment-as in the United States may occur under the Assimilative Crimes Act, 62 Stat.

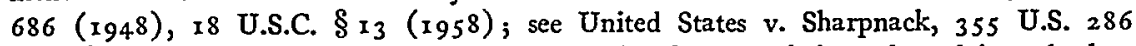
( 1958 ) - the rationale seems to be that those other laws are being adopted into the law of the government whose courts are trying the accused. However, the Court's remarkespecially when applied to Girard's offense of homicide-may have a more profound import. If the jurisdiction of the sovereign nation is truly "exclusive," absent consent, then it would seem to mean that at the outset the United States would lack any jurisdiction over any of its personnel who were in the foreign country. In other words, if the statement is taken literally, the United States had no jurisdiction to try Girard for killing a Japanese citizen. In that event, incidentally, could any American civilian court have been given jurisdiction to try Toth for his killing of a Korean in Korea, if the Korean government declined its "consent" for such a trial? Moreover, if the Supreme Court in the Girard case really meant that there was "exclusive" jurisdiction, absent the consent to trial on the part of the "receiving state," is it not true that the "consent" of the foreign government has really created jurisdiction in American courtsmartial? At least, there will be jurisdiction where there was none before. But, to conceive of a foreign government as being able to create American military jurisdiction would clash violently with some of the views expressed in Reid v. Covert, 354 U.S. I (x957). Still other interpretations are possible of the Court's comment in the Girard case, such as that "exclusive" means only "primary." 
of the Constitution. Whence, then, came the power to prosecute him in any sort of American court, whether it were a federal district court sitting with judge and jury in the United States or some type of legislative court? Was the power in the Ross case the product of the treaty between the United States and Japan? Was it a manifestation of American sovereignty, in accord with the principles enunciated in the CurtissWright case? Or was the result in the Ross case merely a reflection of unsophisticated analysis of the problem?

Certainly in light of the Toth holding, which rested on lack of power to utilize military jurisdiction, it would have been highly appropriate in Kinsella v. Krueger for the majority to have explained more fully how the cases it had cited established the existence of a power either to provide substantive rules of conduct for American dependents accompanying the armed forces overseas or to authorize trial by courtmartial to punish violations of those substantive rules. The absence of such explanation left the majority vulnerable to a jibe by Justice Frankfurter that in relying on the Ross case, it had resurrected "an episode of the dead past about as unrelated to the world of today as the onehorse shay is to the latest airplane." 100

\section{The Petition for Rehearing}

During the months after the opinions were filed upholding jurisdiction over the two civilian dependents, a petition for rehearing was filed and granted, Justice Harlan, one of the five justices in the earlier majority, having now determined that further consideration of the result was called for. The Supreme Court specifically invited the discussion of four issues: ${ }^{101}$ (I) "specific practical necessities" for, and "practical alternatives" to, court-martial jurisdiction over civilian dependents overseas; (2) relevant historical evidence, especially as to whether "the Art. I, $\S 8, \mathrm{cl}$. 14 , power was thought to have a fixed and rigid content or rather that this power, as modified by the Necessary and Proper Clause, was considered a broad grant susceptible of expansion under changing circumstances"; (3) the relevance overseas and in time of peace of any distinction between civilian employees and dependents; and (4) the relevance for "court-martial jurisdiction over civilian dependents overseas in time of peace, of any distinctions between major crimes and petty offenses.” furter).

${ }^{100}$ Kinsella v. Krueger, 351 U.S. 470,482 (1959) (reservation of Justice Frank-

${ }^{101}$ Reid v. Covert, 352 U.S. 901 ( 9566$)$. 
The practical necessities, which are the subject of the Court's first issue, had already been adverted to in its original opinion in Kinsella $v$. Krueger. ${ }^{102}$ They exist chiefly because of the difficulties, expenses, and delay involved in trying before an American civilian court in this country an offense which occurred overseas. The suggestion has also been made that some type of special American courts might be established to try such crimes abroad. ${ }^{103}$ Even with such courts, however, no method for assuring trial by jury seems feasible. Moreover, such courts could not be convened in a foreign country without the consent of the government involved; and any such tribunals would be so reminiscent of occupation courts or the now-discredited rights of extraterritoriality, that such consent might not be forthcoming. Indeed, if American courts do not consider that civilian dependents accompanying the armed forces overseas are so closely connected with their military mission as to be amenable to military jurisdiction, it would be difficult to persuade a foreign government that American national interests require a new grant of extraterritoriality, so that American civil courts can sit to try these persons abroad. ${ }^{104}$

Short of a flat refusal to permit such courts to sit within its borders, the foreign government might simply decline aid in obtaining evidence or witnesses-and might thereby impede the functioning of such courts. And who will be the attorneys to represent defendants there? That the results in these courts would equal in fairness, much less excel, those of

\footnotetext{
${ }^{109}$ See also the discussion of the Toth case in the text at note 52 supra; the concurring opinions of Justices Frankfurter and Harlan in Reid v. Covert, 354 U.S. I (1957); and the opinion of Judge Latimer in United States v. Burney, 6 U.S.C.M.A. 776, 21 C.M.R. 98 (1956). In an interestiug variant of the "Brandeis brief" technique, government counsel submitted statements from several commanding officers overseas to the effect that it was necessary for them to have jurisdiction over American civilians accompanying the armed forces overseas if they were fully to perform their military responsibilities. Counsel for the civilian dependents attacked these statements as being ex parte, self-serving declarations. In attempting to show the practical necessities for military jurisdiction over civilians, the Government submitted the following information as to the large number of civilians overseas with the armed forces: Germany, 173,516 (among them 162,8II dependents); Japan, 80,807; the United Kingdom, 48,138; France, 42,038; the Philippines, I4, III; Ryukus (Okinawa), 13,085; French Morocco, ro,40r; Canada, Newfoundland, and Labrador, 8,492; Italy, 8,092; Bermuda, 5,387; Libya, 4,865; Spain, 4,766; Cuba, 3,195; Formosa, 2,839; Turkey, 2,715; the Azores, 2,644; Greece and Crete, $1,29 \mathrm{I}$; and in other countries there are smaller civilian contingents of dependents and employees accompanying the American armed forces.

${ }^{103}$ See Note, 71 HARV. L. REv. 712 (1958), which contains an excellent discussion of the alternatives.

${ }^{104}$ SNEE \& PYE, op. cit. supra note 56 , at 44.
} 
courts-martial acting pursuant to the Uniform Code of Military Justice is highly questionable. ${ }^{105}$

So far as the Court's first issue is concerned, it seems apparent that absent military jurisdiction over civilian dependents, their punishment will generally be forthcoming from a foreign court-if forthcoming at all. Despite the presence of some assurances of a fair trial in such courts, ${ }^{100}$ this alternative has not always been viewed as highly attractive. ${ }^{107}$

With respect to the second issue-historical evidence concerning military jurisdiction over civilian dependents-it should be remembered that until recently, the United States had not stationed large armed forces overseas and consequently the occasion for court-martialling American dependents abroad had not arisen. Thus, at the outset, the probability was rather great that the Court, if so inclined, could shrug off purported historical evidence as "inconclusive" - just as was done in the School Segregation Cases. ${ }^{108}$

In response to the third issue, neither government counsel nor counsel for the two dependents made any effort to distinguish dependents from employees. The same necessities apply to each-the crimes of either could have a very disruptive effect on military morale and discipline; both are closely identified in the eyes of the foreign government and its citizens with the American armed forces; both enjoy a large number of special privileges by reason of their intimate contact with the armed forces-but neither can be conveniently tried except in a courtmartial or a foreign court. ${ }^{109}$ Furthermore, both the dependent and the

\footnotetext{
${ }^{105}$ There is no point in recapitulating here what has already been said concerning the advantages and disadvantages of an accused who is being tried by court-martial. It may be worth noting, however, that various proposals have been made to require for criminal trials in federal civil courts some of the safeguards familiar to military justice. Among these are the warning against self-incrimination prior to interrogation of a suspect and a strengthened right of counsel for an accused.

${ }^{100}$ EvereTt, op. cit. supra note $\mathrm{I}$, at 43 ; SNEE \& PYE, op. cit. supra note 56 , at 106-1 6 .

${ }^{107}$ Wilson v. Girard, 354 U.S. 524 (1957).

${ }^{108}$ Brown v. Board of Educ., 347 U.S. 483,489 (1954).

${ }^{109}$ Of course, there will probably be no prosecution in a foreign court unless the foreign government has some interest of its own in prosecuting; it would probably lack such an interest when any harm complained of had primarily been suffered by Americans and their property. As to dependents and employees, it might well be noted that although the employee is often situated to do more harm than a dependent to the military mission, there are many more dependents than employees abroad with the armed forces, and, therefore, the cumulative impact of dependents might be as great as, or greater than, that of employees.
} 
employee are overseas and away from American civil courts by their own volition.

The fourth issue seeks to adduce some distinction based on the gravity of the offense involved-a distinction between major crimes and petty offenses. The fifth amendment does specify that "capital, or otherwise infamous crime" does demand a grand jury indictment-a distinction thereby being drawn between felonies and misdemeanors. Moreover, it has been held that the jury trial requirement of article three of the Constitution and of the sixth amendment does not apply to "petty offenses," whatever that term may mean. ${ }^{110}$ It is not completely clear, however, that even petty offenses are exempt from the requirement of trial by a judge holding life tenure.

Certainly, before the petition for rehearing was granted, no historical evidence had been produced and no suggestion had been made to the effect that a distinction should be made as to military jurisdiction over civilian dependents abroad in accord with the gravity of the offense. Moreover, in terms of effect on the armed forces, no such distinction between major crimes and petty offenses is completely satisfactory, since the cumulative effect of many minor infractions may be as severe as that arising from a few major transgressions. ${ }^{111}$ In retrospect, the most significant thing, in light of later developments, may be that the Court's fourth issue gave no intimation whatsoever of any contemplated jurisdictional distinction between capital and noncapital cases; nor was any such distinction attempted thereafter by counsel on either side.

\section{IV}

\section{American Civilians Abroad-the i957 Version}

\section{A. The Opinion of Justice Black}

In 1957, the Supreme Court, taking its second look at Reid v. Covert, held that there was no jurisdiction to court-martial civilian dependents for capital offenses committed overseas in peacetime. Justice Black, writing for himself, Chief Justice Warren, Justice Douglas, and Justice Brennan, emphasized at the outset that when acting against its

${ }^{110}$ As to "petty offenses" see $E x$ parte Quirin, 317 U.S. 1, 39 (1942); District of Columbia v. Clawans, 300 U.S. 617 (1937); 62 Stat. $68_{4}$ (1948), 18 U.S.C. $\$ \S$ I (3), $340 x$ (1958); Frankfurter \& Corcoran, Petty Federal Offenses and the Constitutional

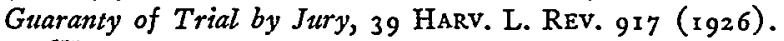

${ }^{111}$ Sometimes the petty offense can be satisfactorily disposed of administrativelywithout resort to any kind of court. However, there may already be too great a tendency of the armed services to resort to "administrative" action as a means of punishment. See EVERE'T, op. cit. supra note 1 , at 123,135 . 
citizens abroad, the United States is not free of the Bill of Rights. According to him, the express wording of article three, section two ${ }^{112}$ mirrors the extraterritorial constitutional protection granted to American citizens; and under the "obvious meaning" of that wording, this protection "is applicable to criminal trials outside of the States as a group without regard to where the offense is committed."13 Justice Black does not explain why this "obvious meaning"-like the "plain meaning" of article one, section eight, clause fourteen of the Constitution which he discovered in Toth $v$. Quarles ${ }^{114}$ - was not earlier perceived; ${ }^{115}$ nor why it would have been impermissible to construe the provision in article three, section two for jury trial of crimes "not committed within any state" as being directed to offenses committed on the high seas or in American territories or possessions, or, at the very least, only to trials which were to take place in areas where the United States was sovereign.

The Black opinion refused to concede that some of the rights provided in the Bill of Rights are less "fundamental" than others, and, therefore, inapplicable outside the United States. ${ }^{116}$ With respect to Hawaii, the Philippines, and Puerto Rico, however, the Supreme Court long ago did make such a gradation of rights and held that grand jury indictment and trial by a common-law jury were not indispensable there. ${ }^{117}$ Of course, in a different constitutional context, the Supreme Court has long been on record that certain rights, being part of a concept of "ordered liberty," are more fundamental than others. ${ }^{118}$ Could it not equally as well be said that some rights are so intertwined with the concept of a free and democratic government that they do follow the flag everywhere, but that other rights-among them that of indictment and trial by jury - do not apply in geographic areas where other governments hold sway and are primarily responsible for providing the political and judicial institutions?

Justice Black disposed swiftly of In re Ross-so heavily relied on in Kinsella v. Krueger, but now described as "one of those cases that cannot be understoood except in its peculiar setting; even then, it seems highly unlikely that a similar result would be reached today." As he pointed

\footnotetext{
${ }^{112}$ Reid v. Covert, 354 U.S. I (1957).

${ }^{113} I d$. at 8.

${ }^{114}$ Discussed at note 49 supra.

${ }^{115}$ For example, why was it overlooked when the Ross case was decided?

${ }^{216}$ Reid v. Covert, 354 U.S. I, 8-9 (1957).

${ }^{117}$ See the cases cited note 96 supra.

${ }^{118}$ Palko v. Connecticut, 302 U.S. 319 (1937).
} 
out, the declaration in the Ross case that the "Constitution can have no operation in another country" had long ago been repudiated. ${ }^{119}$

To the Government's contention that the international agreements entered into by the United States with Great Britain and with Japan had created military jurisdiction, Justice Black answered "that no agreement with a foreign nation can confer power on the Congress, or on any other branch of Government, which is free from the restraints of the Constitution." 120 Otherwise, the Constitution could be amended by treaties, or even by executive agreements. He distinguished and limited Missouri v. Holland $d^{121}$ by emphasizing that it involved no conflict between a treaty and a limitation stated by the Constitution. Instead, there was at issue merely the relationship between treaty power and the tenth amendment's reservation to the states or the people of all power not delegated to the federal government. This viewpoint will comfort those who have long feared that Missouri v. Holland could be construed to permit removal by treaty of constitutional safeguards. But Justice Black's analysis does not destroy the possibility that treaty-making can be a means of centralization of authority through transfer to the federal government of activities that, absent a treaty and by virtue of the tenth amendment, would remain solely with the states.

This opinion then argued that the "natural meaning" of "land and naval forces" in article one, section eight, clause fourteen of the Constitution "does not extend to civilians-even though they may be dependents living with servicemen on a military base."122 Justice Black reasoned that civilian dependents either are in the "land and naval forces" nowhere or everywhere-including the United States itself;

${ }^{120}$ Reid v. Covert, 354 U.S. I, I2 (1957). For cases that have extended constitutional protection overseas, see Burns v. Wilson, 346 U.S. I37 (1953); Wade v. Hunter, 336 U.S. 684 (I949); Balzac v. Porto Rico, 258 U.S. 298 (I922); United States v. Curtiss-Wright, 299 U.S. 304 (1936).

${ }^{120}$ Reid v. Covert, 354 U.S. I, 16 (1957).

${ }^{121}$ Discussed in text accompanying note 87 supra. Interestingly, Justice Black apparently chose to ignore completely in this connection United States v. Curtiss-Wright, 299 U.S. 304 (1936).

${ }^{122}$ Reid v. Covert, 354 U.S. I, 19 (1957). In $\mathrm{n} .38$ to the opinion of Justice Black, there is quoted the statement of Colonel Winthrop, the "Blackstone of Military Law," that the Constitution "clearly distinguishes the military from the civil class as separate communities. It recognizes no third class which is part civil and part military ....." WINTHRop, op. cit. supra note 48 , at I06. The Government took the position that Colonel Winthrop did not live in a time when large American forces with accompanying civilian dependents and employees were operating overseas, where no American civil courts were readily available, and that his comments were inapplicable to the contemporary situation. 
and in his view the former alternative is far preferable. So far as the necessary and proper clause is concerned, he found no authority there to extend congressional power beyond the class described in article one, section eight, clause fourteen-the "land and naval forces." And this class does not include civilian dependents!

At this point in his opinion Justice Black sounded the alarm that a different interpretation of the necessary and proper clause would extend military jurisdiction and "every extension of military jurisdiction is an encroachment on the jurisdiction of the civil courts."123 Here lurks a misconception, for a perusal of the practical alternatives indicates rather clearly that the real choice is between court-martial and trial in a foreign court. Heretofore, no pressing reason has been given why American courts should be especially solicitous to avoid the "encroachment" of our military jurisdiction on that of foreign courts, even foreign civil courts.

Moreover, for an "encroachment" to take place, there must have existed some civil court jurisdiction in the first place. Now consider the case of Mrs. Covert, who is being punished for killing her husband while in England. Under American statutory law, the only basis for arguing that any crime has occurred is the circumstance than an article of the Uniform Code of Military Justice, which prohibits murder, was violated. ${ }^{124}$ The only premise for applying the Code to Mrs. Covert, however, was the assumption that she is part of the "land and naval forces"; and now Justice Black has said that she was not in this category, so that there is no power "to make Rules" as to her conduct.

What, then, if Congress enacts a statute which makes it punishable for an American wife to kill her husband in England? Whence flows the power to enact such a law? Admittedly there are cases that allow punishment by courts sitting in the United States of offenses committed overseas. ${ }^{125}$ The hypothetical case, however, does not arise on an American ship and does not involve some direct injury to the United States, such as conspiring to defraud the United States or counterfeiting. There are several dicta indicating that, even so, the United States has the authority to punish its citizens wherever they commit an offense; ${ }^{126}$ and In re Ross would appear to substantiate that position. By discrediting In re Ross, however, and adopting a very narrow interpretation of congressional power under the Constitution, Justice Black has provoked the

\footnotetext{
${ }^{123}$ Reid v. Covert, 354 U.S. I, 19 (1957). (Emphasis added.)

${ }^{194}$ Uniform Code of Military Justice art. I18, $70 A$ Stat. 72 (1956), 1o U.S.C. $\S 918$ (1958).

${ }^{125}$ See cases cited at note 36 supra.

${ }^{120}$ Supra note 99.
} 
question how an American federal court could constitutionally be given the power to try a crime committed overseas, like Mrs. Covert's alleged murder of her husband, unless she were part of the "land and naval forces." And so, again, one must question the danger of "encroachment" by military jurisdiction in this type of situation.

Some of these difficulties, which are posed by a narrow construction of congressional legislative power under article one, section eight of the Constitution suggest that Justice Black's result might have been more palatable had it been rested solely on the limitations of article three, section two and of the fifth and sixth amendments-limitations that define the permissible means of exercising congressional power to punish, rather than the scope of the underlying power. Of course, under Justice Black's interpretation of the fifth amendment, the applicability of that amendment to civilian dependents wheresoever located is apparent. He reasoned that "the exception in this Amendment for 'cases arising in the land or naval forces' was undoubtedly designed to correlate with the power granted Congress to provide for the 'Government and Regulation' of the armed services."127 Civilian dependents overseas do not fall under the "land and naval forces" within article one, section eight, clause fourteen of the Constitution; and he concludes that undoubtedly the exception in the fifth amendment was not designed to deprive of the grand jury safeguard a person who is outside the court-martial jurisdiction of Congress in the first place. This correlation by Justice Black of the fifth amendment with clause fourteen is somewhat ironic, since, as heretofore noted, use of the same technique in the Toth case would have tended to produce a different result there.

The opinion by Justice Black commented:128

We recognize that there might be circumstances where a person could be 'in' the armed services for purposes of Clause $I_{4}$ even though he had not formally been inducted into the military or did not wear a uniform. But the wives, children, and other dependents of servicemen cannot be placed in that category, even though they may be accompanying a serviceman abroad at Government expense and receiving other benefits from the Government.

It is unclear what Justice Black intended with his reference to persons who were in the armed forces although not in uniform. Government counsel took hope that by this remark Justice Black was placing civilian employees within the scope of court-martial jurisdiction. ${ }^{129}$ In

\footnotetext{
${ }^{297}$ Reid v. Covert, 354 U.S. r, 22 (1957).

${ }^{128}$ Id. at 22-23.

${ }^{220}$ The opinion contained various references to the shortcomings of courts-martial
} 
light of his opinion as a whole, and especially its denunciation of the dangers of military authority, however, this hope-it could have been readily predicted-would prove ill-founded.

The opinion insisted that the situation of civilian dependents cannot be distinguished from that involved in Toth v. Quarles, where the proposed exercise of military jurisdiction as to an ex-serviceman was held unconstitutional..$^{130}$ Of course, Toth had absolutely no connection with the armed services when action against him was commenced; but the relationship of the civilian dependents to the military existed both at the time of the offense and at the time of trial. Undeniably, however, the general approach of the court's opinion in the Toth case-and especially the acute fear of military jurisdiction in general-set the stage for Justice Black's reasoning in Reid v. Covert.

With reference to the lower court opinions upholding military jurisdiction over various civilians closely related to the armed forces, the opinion emphasized that these cases concerned civilians "performing services for the armed forces 'in the field' during time of war" (Justice Black's emphasis). It added: ${ }^{\mathbf{1 3 1}}$

To the extent that these cases can be justified, insofar as they involved trial of persons who were not "members" of the armed forces, they must rest on the Government's "war powers."

Seemingly, in such instances, any exception to trial by jury and other safeguards would be based on the circumstance that for such cases, military trial was permitted from "a time prior to the adoption of the Constitution."132 The analogy, of course, would be to $E x$ parte Quirin which, in a wartime prosecution, denied a jury trial to eight spies, because spies had no right to jury trial under the common law or the law of war. ${ }^{133}$

\section{B. The Concurring Opinions}

Concurring only in the result, Justice Frankfurter delineated the issue narrowly as concerning only civilian dependents overseas charged with a capital crime in time of peace. According to him, "no one, however, challenges the availability to Congress of a power to provide for trial and punishment of these dependents for such crimes."134 (Of

and the possibility that Congress might regress from the comparative enlightenment of the Uniform Code of Military Justice to a more primitive system.

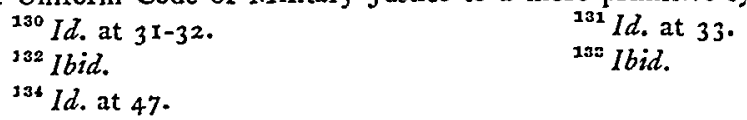


course, it is not shown clearly that either Justice Frankfurter or his brethren have fully considered all the implications of Justice Black's narrow interpretation of the clause fourteen power-some of which implications have been examined earlier in this article).

Justice Frankfurter referred to the possibility that when construed along with article one, section eight, clause fourteen of the Constitution, the necessary and proper clause may sometimes empower Congress to provide for court-martial of civilian dependents overseas. He drew a distinction as to capital cases, however, and considered that where a capital offense is charged, no such power exists.

His opinion re-examined in their historical setting the import of the Insular Cases and of In re Ross-precedents that had been heavily relied on by the Court in its original opinion in Kinsella v. Krueger. ${ }^{135}$ The former decisions, Justice Frankfurter concluded, rested on the power provided in article four, section eight of the Constitution for "Congress to deal with 'Territory' and other Government property"; ${ }^{136}$ and this power would not be available to support court-martial jurisdiction in a foreign country. The Ross case, he remarked, reflected the longestablished international practice concerning consular courts; it "is not rooted in any abstract principal or comprehensive theory touching constitutional power or its restrictions."137 What continued vitality, if any, In re Ross might have, Justice Frankfurter found it unnecessary to determine, in light of his view that article one, section eight, clause fourteen of the Constitution-even when interpreted in the light of the necessary and proper clause-does not furnish in the present cases a sufficient basis for court-martial jurisdiction.

Justice Harlan, also concurring only in the result, stated that he could find "no other constitutional power" than article one, section eight, clause fourteen, to which article 2(II) of the Code can be related. ${ }^{138} \mathrm{He}$ declined to discard In re Ross and the Insular Cases "as historical anomalies," but also refused to accept them as signifying that the "safeguards of Article III and the Fifth and Sixth Amendments automatically have no application to the trial of American citizens outside the United States, no matter what the circumstances."139 Instead, the question is one of which constitutional guarantees should apply outside the United States.

\footnotetext{
${ }^{135}$ Discussed in the text accompanying note 95 supra.

${ }^{136} I d$, at 53 .

${ }^{137} I d$, at 56 .

${ }^{138} I d$, at 66 .

130 $I d$, at 67 .
} 
Ultimately Justice Harlan led up to his conclusion that the safeguards to be applied to courts-martial of civilian dependents overseas should be determined on the basis of a balancing process, very much like that employed in due process cases. Then he pointed out that in at least one situation a distinction as to capital crimes had been made in determining what constitutes constitutional "due process."140 Where a capital crime is involved, he was unwilling to deprive the civilian dependent overseas of a jury trial.

Since the number of capital crimes committed by civilian dependents overseas would presumably not be great, their exclusion from courtmartial jurisdiction, in accord with the views of Justices Frankfurter and Harlan, would probably have little effect on military discipline. ${ }^{141}$ Moreover, the Uniform Code has a provision for treating as noncapital a crime that otherwise would be capital. ${ }^{142}$ Thus, by the simple expedient of treating a case as noncapital, so that a court-martial could not impose a death penalty, it might be possible to retain military jurisdiction over crimes like premeditated murder, for which a death penalty usually is permissible. ${ }^{143}$

In neither of the cases before the Supreme Court had the civilian dependent actually received a death sentence. Under these circumstances, could it have been argued that when military authorities referred each of these cases to a court-martial for trial, they had in legal effect-at least if some sort of presumption of the legality of official action is employed-"directed that the case be treated as not capital," as authorized by the Uniform Code, ${ }^{144}$ and thereby transformed each trial into a non-

${ }^{140}$ Id. at 77 . The distinction has been drawn in "due process" cases involving the right of counsel in state courts. See Betts v. Brady, 3 I 6 U.S. 455 (r942); Powell v. Alabama, 287 U.S. 45 (1932).

${ }^{141}$ In evaluating the capital crime distinction, it may be significant that the use of capital punishment seems to be declining today in many jurisdictions. See Time, March 2 I, I 960, p. I 9 .

${ }^{142}$ Art. $49(f), 70 A$ Stat. 54 (1956), ro U.S.C. $\$ 849$ (f) (1958).

${ }^{143}$ This method could not be employed where there is a mandatory death sentence like that imposed by article ro6, 70A stat. 7 I (1956), ro U.S.C. $\$ 906$ (1958). As has been already observed, however, notes 23-24 supra, that article, which pertains to spying in time of war derives its vitality from the law of war. Even as to situations where the death penalty was only permissible and not mandatory, it could always be argued, "Once a death case, always a death case," although a convening authority had directed that the case be treated as noncapital. However, such an approach would not accord with the view that heretofore has been taken of "capital cases" for military justice purposes.

${ }^{144}$ Uniform Code of Military Justice art. 49 (f), 70A Stat. 54 (1956), Io U.S.C. $\$ 849$ (f) (1958). 
capital case? Admittedly this would be a far-fetched interpretation. ${ }^{145}$ However, it is significant that there was no chance for government counsel either to argue against a capital crime distinction or seek to avoid its application in the present cases-cases where no death sentence had been imposed; and no intimation had been given, even in the issues especially designated for the rehearing, that capital crimes might be deemed to fall within a special exclusion from military jurisdiction.

There can be no doubt that in terms of irreversibility, capital crimes are sui generis, ${ }^{146}$ and special provision for capital crimes is often made by statute. ${ }^{147}$ However, no line of demarcation is drawn expressly by the Constitution; the fifth amendment's grand jury safeguard applied to "a capital, or otherwise infamous crime," and not to a capital crime alone. Nor has any historical evidence been produced that would sustain such a distinction as to military jurisdiction over civilian dependents. Indeed, it is rather hard to understand why article one, section eight, clause fourteen of the Constitution and the necessary and proper clause could create military jurisdiction over noncapital crimes, but at the point of death, the necessity and propriety would suddenly terminate.

On the other hand, Justice Harlan's suggestion that a discriminating analysis should be used in determining which constitutional safeguards apply to courts-martial jurisdiction over civilian dependents seems sound. Such an analysis receives some historical sanction from the Insular Cases and the Ross case. ${ }^{148}$ Moreover, it provides a desirable flexibility, parallel to that which has been relatively successful in the "due process" cases. ${ }^{149}$

Although during the Revolution, American forces did occasionally operate outside the thirteen colonies, ${ }^{150}$ it is unlikely that the founding fathers envisaged a world situation that would compel a relatively per-

\footnotetext{
${ }^{145}$ The Supreme Court has sometimes adopted unexpected interpretations of statutes or of administrative regulations in order to avoid the possibility of conflict with the Constitution. See, e.g., Greene v. McElroy, 360 U.S. 474 (1959) Peters v. Hobby, 349 U.S. 33 I (1955); District of Columbia v. Little, 339 U.S. I (1950).

${ }^{216}$ As to the special nature of capital crimes, see the concurring opinions of Justice Frankfurter in Griffin v. Illinois, 35 I U.S. 12, 2 I (1956), and Uveges v. Pennsylvania, 335 U.S. $437,440-4$ I (1948).

${ }_{147}$ See, e.g., 63 Stat. 94 (194I), I 8 U.S.C. $\$ \S 3$ I4I, 3432 (I958); Fed. R. CRIM. P. 7 (a).

${ }_{148}$ Discussed in the text accompanying note 96 supra.

${ }^{140}$ See, e.g., Wolf v. Colorado, 338 U.S. 25 (1949); Adamson v. California, 332 U.S. 46 (1947); Palko v. Connecticut, 302 U.S. 319 (1937). Admittedly, this approach is lacking in certainty.

${ }^{200}$ For instance, American vessels roamed the seas and an American expedition was made into Canada.
} 
manent stationing of large American military forces overseas. Accordingly, is it unfair to argue that some of the safeguards specified in the Constitution were never intended to be mandatory for any trial conducted overseas under American authority? ${ }^{151}$

Moreover, as a rule of construction, it is presumed that statutes are intended to operate territorially. ${ }^{152}$ Why is it extraordinary to adopt a similar presumption as to constitutional provisions for trial by jury and grand jury indictment? In fact, the reference in article three, section two of the Constitution to crimes "not committed within any state" could readily be construed to embrace only an offense committed overseas that it is intended to try in the United States, and not an offense committed overseas and that it was proposed to try there. ${ }^{153}$

The approach taken by Justice Harlan would allow some judicial leeway in dealing with "external affairs," which, at least when the Curtiss-Wright case was decided, ${ }^{154}$ the Supreme Court thought required a special application of constitutional doctrine. (And the complexities of "external affairs" do not appear to have diminished of late). By holding that "fundamental" rights must be observed even in courtsmartial overseas, the Court would reserve an authority to intervene in the event of abuses of military jurisdiction.

\section{The Dissent.}

Justice Clark's dissent, joined in by Justice Burton, ${ }^{155}$ emphasized at the outset its complete satisfaction with the position taken by the

\footnotetext{
${ }^{151}$ See American Banana Co. v. United Fruit Co., $2{ }_{3}$ U.S. 347 (1909).

${ }^{152}$ It seems interesting that in immigration cases some distinction seems to be made between exclusion and deportation - a circumstance that indicates that territorial concepts may have some influence on constitutional protections. Compare United States v. Ju Toy, 198 U.S. 253 ( 1905 ), with Ng Fung Ho v. White, 259 U.S. 276 (1922). Similarly, under the fourth amendment, a search warrant is usually required as a basis for the search for, and seizure of, fruits and instruments of crime. Overseas there is no American tribunal available to issue such a warrant, however, and the privilege against "unreasonable searches and seizures" must be construed in light of that circumstance. See Best v. United States, I84 F.2d 131 (1st Cir.), cert. denied, 340 U.S. 939 (195 r); United States v. DeLeo, 5 U.S.C.M.A. 148, 17 C.M.R. 148 (1954), and the cases cited therein. The eighth amendment deals with "bail," but there is no American tribunal overseas to set bail. In short, some American institutions cannot be exported overseas; and is it not best to hold that such institutions were never intended for export, instead of holding that because they are incapable of export, the power of the United States to act outside its territorial boundaries should be deemed very narrow?

${ }^{153}$ It could also be argued that the words quoted from art. III $\S_{2}$ may have been directed to offenses arising on the high seas and the like, but not to crimes committed within the boundaries of a foreign country which has its own criminal courts.

${ }^{154}$ Discussed in the text accompanying note 93 supra.

${ }^{155}$ Justice Whitaker did not participate in the decision of the case.
} 
original majority in Kinsella v. Krueger. Justice Clark-after noting that the Court was now overruling or limiting well-established precedents and reversing, setting aside and overruling "two majority opinions and judgments of this Court in these same cases ... entered on June II, I956, less than I2 months ago"-commented : $^{156}$

In substitute therefor it enters no opinion whatever for the Court. It is unable to muster a majority. Instead, there are handed down three opinions. But, worst of all, it gives no authoritative guidance as to what, if anything, the Executive or the Congress may do to remedy the distressing situation in which they now find themselves.

In a similar vein he stated, near the end of his opinion: ${ }^{157}$

My brothers who are concurring in the result seem to find some comfort in that for the present they void an Act of Congress only as to capital cases. I find no distinction in the Constitution between capital and other cases. In fact, at argument all parties admitted there could be no valid differences. My brothers are careful not to say that they would uphold the Act as to offenses less than capital. They unfortunately leave that decision for another day. This is disastrous to proper judicial administration as well as to law enforcement. The Congress and the Executive Department are entitled to know whether a court-martial may be constitutionally utilized to try an offense less than capital. If so, then all that is necessary is to eliminate capital punishment insofar as Article 2(II) offenses are concerned.

Justice Clark relied heavily on dicta in Madsen $v$. Kinsella and Dun can v. Kahanamoku, and on previous lower federal court cases upholding military jurisdiction over civilians closely related to the armed forces. $^{158}$ Although such cases might be distinguished on the grounds that they concerned military jurisdiction in time of war and were not applicable to peacetime trials, ${ }^{159}$ Justice Clark correctly pointed out that

${ }^{156}$ Reid v. Covert, 354 U.S. I, 78 (1957).

${ }^{367} I d$. at 89-9o.

${ }^{168}$ Some of these have been discussed previously in outlining the Government's position in the litigation. See note 84 supra. Among the cases upholding military jurisdiction over civilians accompanying the armed forces overseas are these: Perlstein v. United States, I 5 I F.2d I67 (3rd Cir. 1945); Grewe v. France, 75 F. Supp. 433 (E.D. Wis. 1948); In re Berue, 54 F. Supp. 252 (S.D. Ohio 1944); United States v. Burney, 6 U.S.C.M.A. 776, 21 C.M.R. 98 (1956); United States v. Robertson, 5 U.S.C.M.A. 806, 19 C.M.R. 102 (1955); United States v. Garcia, 5 U.S.C.M.A. 88, I7 C.M.R. 88 (1954); United States v. Weiman, 3 U.S.C.M.A. 2 I6, II C.M.R. 216 (1953).

${ }_{189}$ The Madsen case concerned an offense committed long after hostilities had ceased in Europe; but jurisdiction there could still be subsumed under the law of war and the war power. $C f$. Ludecke v. Watkins, 335 U.S. 160 (1948). 
the war power of Congress has often been broadly construed and could encompass the two cases before the Court. ${ }^{160}$

The dissent emphasized that for civilian dependents overseas-and, therefore, closely related to the armed forces-courts-martial constitute the only feasible alternative to trial in a foreign court. In this connection, it noted that in light of the positions taken by the other Justices, "the use of a system of territorial or consular courts is now out of the question." W11 Within the Toth v. Quarles test of "the least possible power adequate to the end proposed," Justice Clark concluded that the absence of alternatives to article 2 (II) of the Code-that is, alternatives other than trial in a foreign court-makes it "untenable to say that Congress could have exercised a lesser power adequate to the end proposed." $" 162$

\section{V}

\section{American Civilians Abroad-The Last Word}

\section{A. Permutations and Combinations}

In light of the diversity of position reflected in the second edition of Reid v. Covert, the Armed Services ${ }^{163}$ and the Court of Military Appeals ${ }^{164}$ felt free to court-martial civilians overseas who were either dependents charged with noncapital crime, or employees of the armed services, whatever the charge. Four cases soon wended their way to Washington as tests of this narrow interpretation. Kinsella $v$. Singleton $^{165}$ concerned the prosecution of a civilian dependent for a noncapital offense-involuntary manslaughter of her young child. ${ }^{166}$ Grisham v. Hagan ${ }^{167}$ involved a civilian employee of the Army who was tried in France for the capital offense of premeditated murder and con-

${ }^{100}$ Reid v. Covert, 354 U.S. 1, 82 (1957). The cases he cited are Ashwander v. TVA, 297 U.S. 288 (1936) and Silesian-American Corp. v. Clark, 332 U.S. 469 (1947). The former states, at 327 ; "We may take judicial notice of the international situation at the time the Act of 1916 was passed." It adds that building the Wilson Dam was "adopted to the purposes of national defense." The latter case announces, at 476 , that ". . . we think reasonable preparation for the storm of war is a proper exercise of the war power." See also cases cited at note 23 supra.

101 Reid v. Covert, 354 U.S. 1,87 (1957).

${ }^{102} I d$, at 89 .

${ }^{103}$ Note, 7 I HaRv. L. Rev. 7 12, $7 \times 3$ (1958).

104 United States v. Dial, 9 U.S.C.M.A. 54r, 26 C.M.R. 32 ( 1958 ); United States v. Wilson, 9 U.S.C.M.A. 60, 25 C.M.R. 322 (1958).

${ }_{105} 361$ U.S. 234 ( 1960 ) (arising in Germany).

${ }^{100}$ The defendant's husband, a soldier, was convicted by court-martial for the same offense and sentenced to confinement.

${ }^{107} 36$ r U.S. 278 (1960). 
victed of unpremeditated murder, a noncapital offense. In McElroy v. Guagliardo ${ }^{168}$ and Wilson v. Bohlender, ${ }^{169}$ a civilian employee had been court-martialled for a noncapital offense.

\section{B. The Opinion of the Court}

In each case, the Supreme Court rejected military jurisdiction; and, somewhat amazingly, the opinion of the Court was delivered in each instance by Justice Clark, who had been the apostle of courts-martial in the Reid v. Covert litigation. Chief Justice Warren and Justices Douglas, Black, and Brennan joined him. In the Singleton case, involving the civilian dependent, Justice Clark noted at the outset that the "question is not one of first impression."170 Then, he referred to the 1956 opinion in Kinsella v. Krueger, where "we decided by a bare majority that the the article was a valid exercise of the power of the Congress under Art. 4, $\S 3$, to 'make all needful Rules and Regulations' for the 'Territories' of the United States."171 Of course, there is some presumption of the correctness of Justice Clark's explanation of that earlier opinion, which he wrote; however, his explanation will prove disquieting to one who read that opinion. It seems to say that a majority of the Court in 1956 had concluded that Great Britain and Japan, locations of the two homicides there involved, were American "territories"startling news, to say the least.

The Court's opinion next noted that ultimately a majority of the justices concluded in Reid $v$. Covert that, in capital cases, trial by courtmartial of civilian dependents overseas "could not constitutionally be justified."172 Since Justice Clark and his four brethren could find no evidence of any constitutional distinction between capital and noncapital offenses with respect to congressional power under article one, section eight, clause fourteen of the Constitution, and since the distinction seems to have originated with Justices Frankfurter and Harlan-without the aid of counsel ${ }^{173}$ - the majority concluded that noncapital offenses com-

\footnotetext{
${ }^{163}{ }_{361}$ U.S. 281 (1960). Two airmen, tried as co-conspirators, were convicted by court-martial for the offenses, which had allegedly been committed in Morocco.

${ }^{160} \mathrm{Ibid}$. Bohlender's offense had been committed in Berlin; and possibly, because of Berlin's special status, military jurisdiction could have been justified under the law of war. The Court declined, however, to consider this possibility, because it had been suggested by the Government as an afterthought and the case had not been tried on that theory.

${ }_{170} 361$ U.S. at 236.

171 Id. at 237 .

${ }^{172} I d$. at 238 .

${ }^{173}$ Neither side had argued for such a distinction in the Reid $\%$. Covert litigation.
} 
mitted by civilian dependents overseas should also be exempt from military jurisdiction.

The rejection of the proposed distinction is completely logical; but the following palpable bit of illogic was adduced by Justice Clark to support his contention: ${ }^{174}$

Another serious obstacle to permitting prosecution of noncapital offenses, while rejecting capital ones, is that it would place in the hands of the military an unreviewable discretion to exercise jurisdiction over civilian dependents simply by downgrading the offense, thus stripping the accused of his constitutional rights and protections. By allowing this assumption of the "garb of mercy", we would be depriving a capital offender of his constitutional means of defense and in effect would nullify the second Covert case. . . .

It is a novel concept of evasion to claim that the Government evades safeguards accorded in death cases by not trying a person on a possible capital charge. The purpose of those safeguards has been served, and, therefore, the reason for them has vanished. Is it an evasion of the grand jury safeguard when a prosecutor charges a defendant with a misdemeanor instead of a possible felony? ${ }^{175}$

Justice Clark's participation in the rejection of a distinction for capital crimes raises an interesting question about the proper scope of the doctrine of stare decisis. In the final disposition of Reid v. Covert-as Justice Clark himself noted there forcefully in his dissent ${ }^{170}$ - there was no majority against military jurisdiction except in capital cases. Was Justice Clark free, therefore, to argue that he still thought that the result was erroneous in Reid v. Covert, that he did not see any logical distinction between capital and noncapital offenses, but that, to confine the previous error to as narrow a scope as possible, he would adopt that distinction? ? $^{177}$ And to what extent were Justices Whitaker and Stewart, who had not participated in Reid v. Covert, free to reexamine the extent

\footnotetext{
${ }^{174} I d$. at $244-45$.

${ }^{175}$ Later in his opinion Justice Clark argued that application of a capital-noncapital distinction "would free from military prosecution a civilian accompanying or employed by the armed services who committed a capital offense, while the same civilian could be prosecuted by the military for a noncapital crime." Id. at 248 . At this point, the Court was clearly assuming that the offense could not be downgraded from capital to noncapital and that "once a capital case, always a capital case." This is an obvious contradiction of the premise for the argument quoted in the text accompanying note 174 supra.

${ }^{176}$ Quoted in the text at note 156 supra.

${ }^{177}$ Ibid. The passages quoted from his dissent certainly tend to create the impression that he then felt perfectly free in the future to uphold military jurisdiction except for capital crimes.
} 
of congressional power to establish military jurisdiction over civilians? In answering those questions, it should be recalled that only four justices ruled in Reid v. Covert that civilian dependents overseas in time of peace were placed by the Constitution completely beyond the authority of courts-martial. In so far as the importance of precedents is concerned, it might also be worthwhile to remember the remarks by Justice Clark in his Reid v. Covert dissent concerning the overthrow of precedents, even in the same case. ${ }^{178}$

The majority looked to the "landmark" case of Toth v. Quarles for its premise that considerations of discipline cannot provide an excuse for "new expansion of court-martial jurisdiction at the expense of normal and constitutionally preferable systems of trial by jury."179 It has heretofore been emphasized ad nauseam that the encroachment here complained of will exist only if American civil courts do have jurisdiction; and strong doubt has been expressed whether the American civil courts do, for any practical purpose, have a jurisdiction to punish the acts of civilian dependents abroad. The choice is between courts-martial and foreign courts-not courts-martial and American civil courts.

In dealing with civilian employees, Justice Clark announced for the majority that there is no military jurisdiction-whether for capital or noncapital offenses. In so far as the historical evidence is concerned, the conclusion was this: ${ }^{180}$

Although it is true that there are materials supporting prosecution of sutlers and other civilians by courts-martial, these materials are "too episodic, too meager, to form a solid basis in history, preceding and contemporaneous with the framing of the Constitution, for constitutional adjudication."

The language quoted here by the majority is that used by Justice Frankfurter's concurrence in Reid v. Covert ${ }^{181}$ to describe the historical evidence adduced there by the Government to show military jurisdiction over civilians in general and civilian dependents in particular.

The majority's opinion is weakest when it seeks to suggest some alternatives. One solution envisaged, and purportedly derived from the case of $E x$ parte Reed, ${ }^{182}$ decided in 1879 , would involve the signing by civilian employees of agreements to submit to military jurisdiction.

\footnotetext{
${ }^{178}$ Ibid.

${ }^{170}$ Kinsella v. United States ex rel. Singleton, 36 I U.S. 234, 239-40 (1960). (Emphasis added.)

${ }^{180}$ McElroy v. United States ex rel. Guagliardo, 36I U.S. 281,284 (1960).

${ }^{181} 354$ U.S. at 64 .

182 I00 U.S. I3 ( 1879$)$.
} 
Whether this expedient could also be used to provide jurisdiction over civilian dependents is not indicated by the Court, but there seems to be no logical reason for distinction.

The difficulty involved here would seem to stem from the concept that although an accused can waive trial by jury with the consent of the prosecution and of the court, ${ }^{183}$ he cannot, merely by his consent, create jurisdiction in a court. ${ }^{184}$ If Congress does not have authority to empower a court-martial to hear the case of a civilian employee or dependent in peacetime, it would seem highly questionable that any agreement to submit to military jurisdiction at all times in the future would suffice for this purpose. ${ }^{185}$ Furthermore, under the majority view of the congressional power "to make rules" for "the land and naval forces" and the narrow interpretation of those "forces," there is a question about the right of Congress to denominate as criminal the conduct of civilian employees and dependents overseas. ${ }^{186}$ To give weight to any such agreement would resemble allowing a federal district court to try a man for a violation of state law merely because he consented to the trial.

If a civilian employee can subject himself to military jurisdiction by his voluntary act in signing a paper to that effect, a tremendous emphasis is being put on the manner in which volition is exercised. What does the paper add to the volition already manifested by going with the armed forces overseas as an employee or dependent in the first placeespecially when a statute is on the books proclaiming that military jurisdiction will attach overseas. ${ }^{187}$

\footnotetext{
${ }^{183}$ Patton v. United States, 28 I U.S. 276 (1930). It should be noted, however, that there the waiver was made in court and subject to all the safeguards of the courtroom, and did not include offenses that might be committed in the future.

${ }^{184}$ At least, jurisdiction over the cause of action or subject matter cannot be acquired by consent. See 21 C.J.S. Coutrts $\S 85$ (1940); 35 id. Federal Courts $\S 83$ (a) (1943); 14 AM. Jur. Courts $\$ 184$ (1938). In light of the Court's analysis in terms of constitutional power under art. I, $\$ 8, \mathrm{cl}$. $\mathrm{x} 4$, these authorities seem applicable. But see, United States v. Garcia, 5 U.S.C.M.A. 88, 17 C.M.R. 88 (1955).

${ }^{185}$ What if the employee or dependent denied full comprehension of the agreement's effect? What about accusations of coercion to sign away valuable constitutional rights?

${ }^{386}$ At least, where there is no rather direct interference with governmental functions, like that involved in United States v. Bowman, 260 U.S. 94 (1922).

${ }^{187}$ It is probably old-fashioned to argue that one should be presumed to know the law-even when it has been well-publicized, as was done with the Uniform Code of Military Justice. However, there is probably little likelihood that civilians going overseas would have greater understanding of the significance of signing an agreement to be subject to military jurisdiction.
} 
The second alternative proposed by the Court to meet any military needs for control over civilian employees relied on the power to put a man in uniform. "If a doctor or dentist may be 'drafted' into the armed services ... there should be no legal objection to the organization and recruitment of other civilian specialists needed by the armed services."1188 Thus, the culmination of a series of cases which express a desire to protect American citizens from the alleged abuses of courts-martial is the suggestion that more American citizens be drafted into the armed services, where they will be subject not only to courts-martial, but also to all other liabilities and responsibilities of a serviceman. Here is a proposed alternative probably even less attractive than surrender of Americans to foreign tribunals for trial-a surrender that many thought would be the necessary concomitant of Reid v. Covert.

\section{The Opinion of Justices Harlan and Frankfurter}

Justice Harlan, joined by Justice Frankfurter, agreed with the majority that civilian employees cannot be tried by court-martial for capital crimes. For noncapital crimes, however, these two jurists conclude that military jurisdiction does exist as to both civilian dependents and employees. With respect to the result in Reid v. Covert, the opinion remarked that no single view "commanded the assent of a majority of the Court"; then it added that only on a "faulty view" of the Covert case does it control as to noncapital crimes. ${ }^{189}$

These two Justices considered that article one, section eight, clause fourteen of the Constitution must be interpreted in the light of the Necessary and Proper Clause and that it is not the military "status" of an accused that controls his amenability to military jurisdiction, but instead "the closeness or remoteness of the relationship between the person affected and the military establishment."190 In light of the close relationship to the armed forces of civilian employees and dependents overseas, they fall within military jurisdiction; and, under the view taken in the majority opinion, the United States will be hampered, Justice Harlan claimed, in dealing with complicated international problems that have required American forces to be stationed overseas in the first place.

\footnotetext{
${ }^{288}$ See McElroy v. United States ex rel. Guagliardo, 361 U.S. 281 (1960). The Court relied here on Orloff v. Willoughby, 345 U.S. 83 (1953) (the doctor draft).

${ }^{180}$ Kinsella v. United States ex rel. Singleton, 361 U.S. 234 (1960).

${ }^{100} \mathrm{Id}$. at 257 .
} 


\section{The Opinion of Justices Whitaker and Stewart}

Justice Whitaker filed an opinion for himself and Justice Stewart, these being the two who had not participated in deciding any of the earlier cases on military jurisdiction. Justice Whitaker stated that the source of any power to court-martial civilians overseas lies in article one, section eight, clause fourteen of the Constitution, and, in his view, this power extends only to the "land and naval forces,"-however that phrase may be defined. The necessary and proper clause does not give authority under clause fourteen to "make Rules" for persons not in the "land and naval forces," no matter how close those persons may be to the armed services, either functionally or otherwise. In a footnote, Justice Whitaker acknowledged that, on this particular point, Justice Stewart disagreed with him and should be counted in the Harlan camp. ${ }^{191}$

Concerning congressional power to enact article 2 (II) of the Code, the opinion remarked: ${ }^{102}$ "Certain aspects of that broad question have recently been determined in Reid v. Covert ...., and though not a Court opinion, I consider that decision to be binding on me." The logical question here is: As to what is the decision "binding"? Is it only "binding" to the effect that civilian dependents cannot be court-martialled overseas for capital offenses? Or that civilian dependents cannot be court-martialled overseas? Justice Whitaker chose the latter alternative because, as to constitutional power, he could find no basis for a capital-versus-noncapital distinction. Just as with respect to Justice Clark's opinion, the question can be raised whether stare decisis really demands that a small constitutional error be expanded into a large error merely because it is impossible to draw a logical line between the two. Or, to put it differently, it would not seem a defiance of stare decisis for five justices-Clark, Whitaker, Stewart, Frankfurter, and Harlan-to have disposed of the cases by holding that as to all noncapital offenses, military jurisdiction did exist for both dependents and employees, even though no majority for military jurisdiction existed as to capital offenses.

Justices Whitaker and Stewart concluded that for civilian employees, the situation is quite different and that these are subject to court-martial for either capital or noncapital crimes. History and necessity, they believed, support the conclusion that the "land and naval forces" include "civilians employed by the armed forces at bases in foreign lands to do

${ }^{201} I d$. at 261 n.2.

${ }^{202} I d$. at 262. (Emphasis added.) 
essential work for the military establishment." 193 With respect to the argument that, so far as the historical evidence shows, civilian employees could only be court-martialled when serving with the armed forces "in the field," this opinion reasoned that "in the field" does not mean only in time of war. Indeed, the concept is such "that armed forces of the United States stationed at bases in foreign lands-where jurisdiction of our civil courts does not extend-must, under turbulent world conditions," be regarded as "in the field."194 The practical necessities and lack of alternatives buttress the conclusion that military jurisdiction extends to civilian employees overseas.

\section{VI}

\section{Evaluation}

\section{A. The Judicial Process}

The complex history of the recent cases on military jurisdiction over civilians reflects the operation of the judicial process almost at its worst. If Reid $v$. Covert had concerned a noncapital case, the outcome would probably have been different. Furthermore, if the first case in the series to reach the Supreme Court had been one involving a civilian employee charged with a noncapital case, it seems even more probable that there military jurisdiction would have been upheld. If, then, the next case had concerned a civilian employee charged with a capital offense, would a majority have rejected any capital-noncapital distinction as illogical and held that military jurisdiction extended to all categories of offenses? And would civilian dependents later have been swept under the umbrella?

Many such questions can be conjured up. And they serve to suggest quite strongly that "the contingencies of judicial review and of litigation" have here played a major part in determining the scope of military jurisdiction. ${ }^{195}$ Some would reply that this is an inevitable concomitant

\footnotetext{
${ }^{103} I d$. at $27 x$.

${ }^{104} I d$. at 276 . Perhaps the rationale of the cases upholding jurisdiction over civilians with the armed forces "in the field" in time of war is that, under such circumstances, it is difficult and disruptive of military operations to have trials in the regular civil courts. Even Ex parte Milligan, 71 U.S. (4 Wall.) 2 (1866), recognized that unavailability of the civil courts was a factor to be considered in ruling on military jurisdiction under martial law. For American armed forces overseas, the American civil courts are often as unavailable in practice as they would be for forces operating in the field. Under these circumstances, should not the same necessity uphold military jurisdiction as has upheld it for the cases arising "in the field"?

${ }^{105}$ Cf. FCC v. Pottsville Broadcasting Co., 309 U.S. 134, I45 (r 940).
} 
of stare decisis. It would be incongruous, however, to argue that stare decisis really had much relevance to the litigation on military jurisdiction-litigation wherein the Supreme Court granted a rehearing, completely reversed itself, and threw into discard a number of long-established precedents.

Since the special exception created by Justices Frankfurter and Harlan for capital crimes played a major role in the drama, it is also worth noting that the distinction between capital and noncapital offenses was virtually conjured out of thin air by these two jurists. It was not suggested by the parties in their briefs in Reid $v$. Covert; nor did the issues specified in connection with the rehearing there give any intimation that such a distinction was being considered. Ironically, too, no death sentence was before the Court; and, if the point had been raised, government counsel might even have argued that under the provisions of the Uniform Code of Military Justice, the cases of the capital dependents had been treated as noncapital. ${ }^{106}$ To heighten the irony, it should also be noted that the likelihood that a civilian dependent overseas would be sentenced to death by a court-martial is almost negligible. Yet, the risk of capital punishment for a dependent seems to have been the tail that wagged the dog of military jurisdiction.

\section{B. Future Constitutional Attacks on the Uniform Code}

Near the beginning of this article, reference was made not only to article 2(II) and 3(a) of the Uniform Code of Military Justice, but also to other articles that pertain to military jurisdiction over civilians. ${ }^{107}$ How many of these provisions can survive constitutional attacks based on the decisions which have been discussed here? As to discharged servicemen held as military prisoners, a well-entrenched precedent exists for allowing court-martial, ${ }^{198}$ and it is doubtful that a majority could be mustered to overturn this decision. If so, the problem might be handled administratively in some instances by delaying the issuance of a discharge to a prisoner and retaining him in the armed services until he has completed his military confinement. ${ }^{100}$

\footnotetext{
${ }^{106}$ See discussion in text accompanying note 144 supra.

${ }^{107}$ See text accompanying note 15 supra.

${ }^{108}$ Kahn v. Anderson, 255 U.S. I (1920).

${ }^{100}$ Delaying the issuance of the discharge might give rise to some administrative problems. Cf. United States v. Washington, 6 U.S.C.M.A. 114, 19 C.M.R. 240 (1955). Since time in confinement is considered "bad time," which must be made good by the serviceman, 72 Stat. $144^{2}$ (1958), 10 U.S.C. $\$ 972$ (1958), there would seem to be no problem about expiration of an enlistment while the serviceman was in confinement.
} 
With respect to article 2 (IO) of the Code, which extends military jurisdiction to civilians with the armed forces "in the field" in time of war, no clear majority of the justices is on record in favor of constitutionality. There is some indication that approval will be given of such jurisdiction, however, although subject probably to a rather limited conception of "in the field." Since any case under this article would, by definition, arise during a war, when, of course, the courts have more of a tendency to uphold military authority, this provision will probably withstand constitutional attack.

Military jurisdiction over all persons on leased areas outside the United States may still be sustainable under the congressional power conferred by article four, section three of the Constitution to "make all needful Rules and Regulations respecting the Territory or other Property belonging to the United States." The dismissed officer's right to trial by general court-martial, as provided by article four of the Code is inconsistent with the basic approach that finally has prevailed in the military jurisdiction litigation-i.e., that one must be in the "land and naval forces" to be subject to court-martial. In McElroy v. Guagliardo, however, the majority-as heretofore noted ${ }^{200}$ - did present an alternative that involved creating jurisdiction by consent; and this principle would seem to allow a court-martial for the dismissed officer, since under article four, he, and not the Government, is seeking trial by courtmartial.

The provisions in the Uniform Code for court-martial of spies and those who aid the enemy seem perfectly sustainable under the law of war as applied in Ex parte Quirin. ${ }^{201}$ The provision for military jurisdiction over certain contempts can likewise be upheld, on the ground that contempts were beyond the right to trial by jury at common law.

\section{Need for New Legislation}

"A half loaf," it has been suggested, "is better than no loaf at all." Accordingly, even one who dislikes the position as to military jurisdiction taken by the Supreme Court must determine whether, by new legislation, Congress can salvage something from the shambles. For the Toth situation, it would appear desirable that Congress enact a provision placing in federal district courts a jurisdiction to punish serious violations of the Uniform Code of Military Justice as to which no charges had been

\footnotetext{
${ }^{200}$ See text accompanying note 182 supra.

201317 U.S. I (1942).
} 
filed before the accused was discharged from the armed services and reverted to civilian status.

With respect to civilians overseas, it might also be wise to provide jurisdiction in the federal district court over acts that, if committed by a serviceman, would constitute violations of the Uniform Code. In most instances, any such trial might be impractical; but there would probably be some cases where all the evidence and witnesses might readily be available for a trial in the United States. A question has been raised earlier in this article about the constitutional basis for enacting substantive criminal legislation to govern the actions of civilian dependents and employees overseas with the armed forces. If they are not in the "land and naval forces," where is the power to "make Rules" for them? On the other hand, there is some precedent for the view that the United States has power to punish the crimes of its citizens, wheresoever committed. ${ }^{202}$ Under the circumstances, there would be nothing to lose by enacting such a statute, and even a fair hope that such legislation would be upheld as constitutional.

\section{International Affairs}

Prior to Reid v. Covert, several precedents seemed to provide reservoirs of congressional power for dealing with international affairs. For instance, Missouri v. Holland $d^{203}$ took a very broad view of the treaty-making power; and the Curtiss-Wright case ${ }^{204}$ affirmed that as to external affairs, the federal government held very wide powers, not all necessarily specified in the Constitution, and which were attributes of the sovereignty inherited from the British Crown. The Ross case $\mathrm{e}^{205}$ indicated that there was even a power to establish courts abroad.

In Reid v. Covert, a narrow interpretation of the treaty power was taken, and the theory advanced in the Curtiss-Wright case was almost ignored. In re Ross was treated as an historical anomaly. And even as to matters with grave international overtones, the Supreme Court has required that Congress find express constitutional authorization for its action, rather than rely on general "sovereignty" or on treaty provisions.

The significance of such rulings for the conduct of American foreign affairs should be obvious. Indeed, the Court's very restrictive concept of congressional and executive power could do great harm to this country's ability to cope with today's crucial international problems. And

\footnotetext{
${ }^{202}$ See cases cited note 99 supra.

${ }^{203} 252$ U.S. 416 (1920).

204299 U.S. 304 (1936).

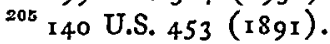


such a concept hardly accords with the oft-heard comment that the American Constitution is a "growing" document.

Expediency is no basis for any interpretation that would, in effect, amend the Constitution. On the other hand, practical considerations should not be totally sacrificed to abstract theory. The decisions as to military jurisdiction over certain civilians are a perfect example of such sacrifice to theory, since the dangers of abuse by the military were not so great as pictured by the Court; the need for military authority was, and is, very pressing; and in many instances, the position of an accused will be harmed, rather than helped, by the absence of court-martial jurisdiction.

\section{E. The Constitution Follows the Flag}

The Supreme Court was definitely correct in repudiating the dictum of the Ross case that the Constitution has no operation outside the United States. It does have, as the cases have long since established. There is still room, however, for a discriminating analysis that would draw a line between those fundamental rights that are exported and those that are not. The refusal to draw any such line commits the United States still further to rigidity in coping with international problems. 